From Communities to

\title{
De Comunidades a Nação. Regionalização do poder, localismos e construções identitárias em Minas Gerais (1821-1831).
}

Nation: Power Regionalization, Localisms and Identitary Construc-

tions in Minas Gerais (1821-1831)

\section{Ana Rosa Cloclet da Silva}

Pesquisadora de pós-doutorado FFLCH-USP

\section{Resumo}

0 texto busca reconstituir o quadro de tensões, contradições e conflitos que perpassaram a simultânea moldagem do Estado e da Nação brasileiros no espaço político da província mineira, focalizando o processo de montagem de uma esfera pública de poder, entre 1821 e 1831. Tratase, especificamente, de perceber no relacionamento entre as esferas de poder local - as Câmaras - e regional - as Juntas Provisórias (1821-1824), sucedidas pelo Conselho Geral e a Presidência da Província (desde 1824) - manifestações das dificuldades em se criar órgãos supostamente representativos dos interesses públicos da província, fruto do embate entre posturas alternativas quanto à melhor forma de se "transformar comunidades em nação".

\section{Abstract}

This article searches to reconstruct the context of tensions, contradictions and conflicts that embased Brazilian National-State building, considering the creation process of the public power in Minas Gerais province, between 1821-1831. Specifically, it focuses the relationship between local - the Câmaras - and regional powers - the Juntas Provisórias (1821-1824), followed by the Conselho Geral and Presidência da Provincia (since 1824) -, understanding the dificulties envolving in the creation of representative instances of province public interests as emerging from the confronts between alternative projects to transform communities in nation.

\section{Palavras-chaves}

nação, identidades, Minas Gerais, regionalismo, elites, Primeiro Reinado.

\section{Keywords}

nation, identities, Minas Gerais, regionalism, elites, First Reign. 
István Jancsó \& João Paulo Garrido Pimenta, "Peças de um mosaico (apontamentos para o estudo da emergência da identidade nacional brasileira)", in: Carlos Guilherme Mota (org.), Viagem Incompleta. Formação: histórias. São Paulo: Ed. Senac, 2000, vol. 1.

Mediante as dificuldades que permeiam o estudo do nacional, bem como a própria definição de Nação, vale recorrer à profícua abordagem de Benedict Anderson. Imagined Communities. Reflections on the Origin and pread of Nacionalism. London/New York: Verso, s.d. Sobre o tema, ver ainda J. Roderick Barman. Brazil. The Forging of a Nation, 1798-1852. California: Standford University Press, 1988, p. 2. Para o caso brasileiro, ver as recentes abordagens cristalizadas na coletânea organizada por István Jancsó, Brasil: Formação do Estado e da Nação. São Paulo: Hucitec, 2003.

Neste sentido, recupera-se a complexidade envolvida na emergência de uma identidade nacional inscrita, nas linhas propostas por Chiaramonte, na múltipla e simultânea convivência de diversos níveis de pertencimento político, expressivos das "identidades políticas coletivas" também diversas. (José Carlos Chiaramonte, "Formas de identidad politica en el Rio de la Plata luego de 1810", in: Boletin del Instituto de Historia Argentina y Americana "Dr. Emilio Ravignani", 3a. série, n. 1, Buenos Aires, 1989, p. 73)

Nuno Gonçalo Monteiro, "Os concelhos e as comunidades", in: José Mattoso (dir.), História de Portugal, vol. 4, Editorial Estampa, p. 309.
0 interesse recentemente despertado pelos processos de formação do Estado e da Nação brasileiros, além de revelar uma inegável sintonia com trabalhos produzidos por historiadores de diversos paises - sob influência da chamada "crise dos Estados-Nacionais contemporâneos" e do aporte teórico-metodológico oferecido pela "Nova História Política" - conduz à incontornável revisitação de abordagens consagradas pela historiografia brasileira, sobretudo da segunda metade do século $X X$, pautadas por ênfases diferenciadas nos aspectos de continuidade e ruptura resguardados pela instável e não linear transição da colônia à nação independente. Particularmente, reconhece-se um esforço em se compreender as singularidades da efetivação da crise do Antigo Regime Português na América e da emergência - não coetânea - dos fenômenos em causa, a partir das diversidades internamente assumidas por estes, inscrevendo-os naquele "mosaico" de formas e significados orientadores de referenciais identitários e projetos políticos alternativos. ${ }^{1}$

Sincronizado com a tendência historiográfica em causa, o presente texto busca reconstituir o quadro de tensões, contradições e conflitos que perpassaram a simultânea moldagem do Estado e da Nação brasileiros no espaço político da província mineira, focalizando o processo de montagem de uma esfera pública de poder, entre 1821 e 1831. Tratase, especificamente, de perceber no relacionamento entre as esferas de poder local - as Câmaras - e regional - as Juntas Provisórias (1821-1824), sucedidas pelo Conselho Geral e a Presidência da Província (desde 1824) - manifestações das dificuldades em se criar órgãos supostamente representativos dos interesses públicos da província, fruto do embate entre posturas alternativas quanto à melhor forma de se "transformar comunidades em nação". 2

De outro modo, pretende-se mostrar como, apesar de encarregadas do engedramento dos mecanismos necessários à edificação de um Império - o "Brasílico" - alternativamente a outro - o "luso-brasileiro" -, estas instâncias foram incapazes de diluírem valores, referenciais e vinculos identitários diversos, reportados a temporalidades também distintas, em nome dos novos ícones associados à "modernidade" política. Ao invés disso, suas persistências - servindo de substrato à atuação e propostas de futuro dos grupos que transitaram para fase nacional delinearam novos níveis e dimensões das polaridades "centro"|"periferia", "unidade"|"diversidade", "mudança"|"tradição", que instabilizaram a afirmação da autoridade pedrina e tensionaram o processo de construção do Estado e da Nação brasileiros. ${ }^{3}$

\section{I - Dispersão e Unidade. A quebra do ordenamento político da sociedade}

Ao debruçar-se sobre o tema da arquitetura dos poderes no Portugal do Antigo Regime, Nuno Monteiro insiste numa particularidade do reino: a "inexistência de poderes formalizados de âmbito regional". A decorrência disso, segundo o autor, está no fato de que "o principal contraponto dos esforços de centralização irregularmente protagonizados pela monarquia, sobretudo depois de meados do século XVII", seriam as esferas do poder local - especificamente os Concelhos Municipais -, marcadamente "aregional e anti-regional". 4 
Caio Prado Jr. Formação do Brasil Contemporâneo. 9a. Ed., São Paulo: Brasiliense, 1969, p. 301.

6

"Sobre honras a que tem direito nas solenidades públicas o Governador e Capitão General", in: Coleção de Ofícios de D.Manoel de Portugal e Castro ao Governo de D. João VI (1814-1821), in: RAPM, Ano IX, Fasc. III e IV, jul-dez de1904, pp. 579-580.

7

Ana Rosa Cloclet da Silva, "Minas na Independência brasileira: o forjamento da unidade", in: Anais Eletrônicos do XIV Encontro Regional de História. ANPUH-MG, UFJF, 25 a 30 de julho de 2004.

8

0 conceito 'liberal" é aqui usado para a compreensão da atuação daquelas elites que, identificadas pela propriedade irão, no contexto da independência e a partir de 1822, atuar no sentido de defender um estreito conceito de liberdade: aquele que, coincidindo com a construção de um Estado nacional constitucional, reportava ao plano da liberdade puramente politica de grupos identificados pela propriedade, ansiosos por um arranjo institucional capaz de dotar-Ihes representatividade politica e, portanto, viabilizar seus interesses materiais especificos. (Maria Emília Prado, "Ordem Liberal, Escravidão e Patriarcalismo: as ambigüidades do Império do Brasil", in: Lúcia Maria Paschoal Guimarães e Maria Emilia Prado (orgs.), 0 liberalismo no Brasil imperial: origens, conceitos e prática. Rio de Janeiro: Revan: UERJ, 2001, pp. 163-189).

9

Neste sentido, a Junta suspendia as "Ordens a que deu princípio para se reunirem os Eleitores" para instalacão de um novo Governo, conforme os Decretos de 29 de Setembro, interpretados como dirigido "a lançar de novo os ferros à Província, ressussitando o anterior despotismo, visto que criando três diferentes Poderes em diversas Representações só com responsabilidades às Cortes, e sem haver na Província uma Autoridade Superior, a que aquelas ficassem sujeitas(...)".("Ofício para o Soberano Congresso", Vila Rica, 7 de Janeiro de 1822, in: RAPM, ano de 1904, vol. IX, pp. 607-610).

10

Convencidos da necessidade de ficarem "o Chefe Militar, os Magistrados, e as Juntas da Fazenda sujeitos ao Governo da Provincia", os liberais da Junta provisória veriam com ressalvas a presença do próprio D. Pedro, revelando um certo indiferentismo quanto à sua partida e opondo-se, ainda, à decisão da deputação mineira de não seguir para Lisboa.("Oficio para a Secretaria de Estado dos Negócios do Reino e Estrangeiros", de $1^{\circ}$. de Março de 1822, in: RAPM, ano de 1904, vol. IX, pp. 612-613. Ver ainda: Salomão de Vasconcellos. $O$ Fico, Minas e os Mineiros na Independência. Belo Horizonte: Imprensa Oficial, 1972, p. 115).

11

Alcir Lenharo, As Tropas da Moderação. 0 abastecimento da Corte na formação política do Brasil: 1808-1842. 2a. Ed., Rio de Janeiro:Secretaria Municipal de Cultura, Turismo e Esportes, 1993.

\section{2}

"Cópia em pública forma de representação enviada a D. João VI por José Teixeira da Fonseca Vasconcellos, Vice-Presidente do governo de Minas Gerais, quando o Rei regressou à Corte de Lisboa, dando conta da situação das Minas Gerais, dentro do quadro das novas orientações políticas", in: Avulsos do Conselho Histórico Ultramarino

- Minas Gerais, MS 544, CX 188, ROLO 174, DOC

25, Biblioteca Nacional do Rio de Janeiro, Seção de Manuscritos.
Com algumas mediações e, seguindo alerta pioneiro de Prado Jr., "com o espírito preparado para toda ordem de incongruências"5, não seria errôneo estender à América portuguesa mais este traço da administração metropolitana, perpetuado durante boa parte do período nacional. A observação é relevante e, a nosso ver, ilumina as tensões que permearam o processo inicial de regionalização do poder em Minas Gerais, marcado pelas profundas incompatibilidades que indispuseram o antigo Governador D. Manuel de Portugal e Castro - expressão da inércia de cunho absolutista, que sobrepujava os costumes, rituais e padrões de hierarquização próprios ao Antigo Regime, à "Lei positiva"6 - com as tendências liberais da 10. e 2a Juntas - eleitas, respectivamente, em 20 de Setembro de 1821 e 20 de maio de 1822 - e estas com algumas Câmaras Municipais, esgarçando um processo conturbado, que esteve longe de acenar com uma automática adesão da província à autoridade pedrina.

Neste sentido, contrariando a tese de que a "especificidade mineira" residira no papel da província como "berço da unidade" e "liberdade" nacionais, temos observado, em reflexões anteriores ${ }^{7}$, que mesmo entre as elites liberais 8 imperava o dissenso em torno do novo arranjo político constitucional a ser estabelecido. Após Dezembro de 1821 - quando chegam a Minas os Decretos lisboetas de 29 de setembro daquele ano - torna-se flagrante a polarização da postura autonomista da Junta ouropretana - em simultânea oposição à perspectiva da perda dos direitos constitucionais adquiridos, associada à postura "recolonizadora" das Cortes $^{9}$, e à ameaça de uma guinada absolutista por D. Pedro ${ }^{10}$ - em relação àquela seguida pela camada de proprietários ligados pelo comércio e pela política ao Rio de Janeiro ${ }^{11}$ - para os quais o Constitucionalismo representava a possibilidade de um aprofundamento de autonomias adquiridas desde, pelo menos, 1808 - respaldada pela atuação do vice-presidente, Teixeira de Vasconcellos ${ }^{12}$, e a dos Deputados eleitos ${ }^{13}$, os quais passaram a gravitar sob a órbita do Príncipe Regente.

A discordância entre os membros da Junta ouropretana e a tendência adesista a D. Pedro não desaparece nem mesmo com o "Fico" - ao qual acataram com evidente frieza ${ }^{14}$-, a partir de quando emerge com especial relevo a questão da definição dos limites da autoridade dos novos poderes provinciais, mediante a constituição de uma instância interna do Executivo. Neste momento, a preservação de autonomias constituídas de longa data e pretensamente consolidadas pelo sistema constitucional era ameaçada, na perspectiva dos membros do Governo mineiro, pelos arranjos institucionais acalentados pelos estadistas que capitaneavam a opção pedrina, cristalizados, em grande medida, no Decreto de 16 de Fevereiro de 1822 - criador do Conselho de Procuradores Gerais das Províncias -, ao qual recusaram dar cumprimento ${ }^{15}$, delineando uma postura eqüidistante em relação a Lisboa e a D. Pedro, confirmada por medidas arbitrárias, que correram à revelia de ambos os poderes. ${ }^{16}$

A mesma diversidade de tendências que envolveu o partido liberal mineiro, marcou o processo da Independência nas outras partes da Província, externando as tensões entre os poderes locais e o Governo 
13

"Comunicação ao Governo Provisório de Minas Gerais (1822), dos deputados eleitos pela Província às Cortes Portuguesas, de não seguirem para Lisboa e dos motivos porque assim deliberaram", 25 de fevereiro de 1822, in: RAPM, 1897, Vol. 2.

As Juntas Governativas e a Independência. Rio de Janeiro: Conselho Federal de Cultura/Arquivo Nacional, 1973, vol 2, p. 861.

15

Justificavam tal recusa pela suposta união e confusão que promoveria entre os Poderes Legislativo e Executivo, nas pessoas dos Procuradores e Ministros de Estado, "com dificuldade de se Ihes "imputar a culpa", e cuja "faculdade de decidir será ilimitada, pois da natureza de qualquer Conselho é não compelir ao reconhecimento, e aceitação, nem produzir obrigação legal(...)". ("Ofício para a Secretaria de Estado dos Negócios do Reino e Estrangeiros", de 22 de março de 1822, in: RAPM, ano de 1904, vol. IX, pp. 611-612).

\section{6}

Dentre estas, destacam-se as inúmeras demissões e admissões do funcionalismo público, a alteração do valor da moeda e mesmo sua cunhagem, a criação de um "Corpo de Tropa de Infantaria intitulado Batalhão Constitucional de Caçadores", comunicada diretamente às Cortes em Oficio de 27 de Fevereiro de 1822 sob alegação de "ser muito proveitosa à Província" e também concorrer "para se firmar o Sistema Constitucional, cuja preservação jamais deixará o Governo de promover com os maiores esforços e sacrifícios". No mesmo sentido, estabelecia ainda que "as ordens do Principe ou das Cortes só se executariam com seu beneplácito".(Francisco Iglésias, "Minas Gerais", in: História Geral da Civilização Brasileira. T. II, vol. 2, 1972, p. 385).

\section{7}

Segundo Wlamir Silva, é possivel cogitar que "a proximidade do poder absoluto, na figura dos funcionários reais, e a adesão dos mesmos a D. Pedro" tenha induzido os liberais da capital a identificarem "o principe com a continuidade do Antigo Regime", fato não verificado nas demais partes da provincia.( Wlamir Silva, "Liberais e Povo: a construção da hegemonia liberal-moderada na Província de Minas Gerais (1830-1834)". Rio de Janeiro:IFCS/UFRJ, 2002, p. 203. (Tese de doutorado), p. 74).

18

"Câmara de São João Del Rei, a 23 de janeiro de 1822", in: As Câmara Municipais e a Independência, op. cit., vol. 2, pp. 353-356.

19

"Câmara de Barbacena, aos 28 de maio de 1822", in: As Câmara Municipais e a Independência, op. cit., vol. 2, pp. 34-36.

\section{0}

"Livro de Acórdãos da Câmara de São João Del Rei", a 4 de abril de 1822, in: As Câmara Municipais e a Independência, op. cit., vol. 2, p. 359.

21

Idem, p. 362.

22

A respeito do processo eleitoral para a escolha das Juntas do Governo Provisório ver: "Primeiras administrações eletivas em Minas Gerais", in: RAPM, Ano I, fac. $1^{\circ}$., janeiro e março de 1896, pp. 97 a 117.

23

As Câmara Municipais e a Independência, op. cit., vol. 2, op. cit., p. 359 .

24

A primeira viagem pedrina a Minas revela os termos de tal negociação. Durante seu percurso pelas diversas Vilas e fazenda, além do status conferido
Provisório. A grosso modo, contrapunha-se aqui a postura da Câmara de Vila Rica - inicialmente mais suscetível à influência do ex-Governador com aquela das Vilas mais afastadas da capital, porém articuladas ao Rio de Janeiro. ${ }^{17}$

Nas Representações destas últimas enviadas ao Governo Provisório, além da oposição à nova forma dos Governos provinciais, decretada pelas Cortes - basicamente, a independência do Governador das Armas e da Junta da Fazenda Pública 18 - e à partida do Principe ${ }^{19}$, acordava-se sobre a adequada "Divisão que cumpre fazer-se dos três poderes; Legislativo, Executivo e Judiciário, dos quais o primeiro reside essencialmente na Nação representada pelos seus Deputados em Cortes, o segundo no Rei ou no Regente, e o terceiro nos Ministros: devendo-se por isso restringirse os poderes, que em o dia vinte de setembro, se conferiram ao Governo Provisional desta Província, com cuja reunião se mostram incompatíveis à tranqüilidade dos Povos e à Dignidade de Sua Alteza Real(...)"20.

A idéia era frisada em outra Representação da Câmara de São João Del Rei, na qual atribuia-se novamente a esta "reunião de poderes", "parte das Deliberações, que se notam no Governo Provisional", depositando-se na viagem de D. Pedro à província as esperanças de que viesse "emendar os erros que à primeira vista se observam na instalação" do mesmo Governo ${ }^{21}$. Neste documento, a Câmara lembrava que a própria legitimidade deste último estava assentada na "vontade dos Povos" - uma vez que a Junta era eletiva 22 - e que esta mesma vontade, "sólida e legitimamente declarada agora pelas câmaras (...) vai estabelecer os justos limites da sua jurisdição".23

A nosso ver, estas tensões que permearam o processo inicial de regionalização do poder, envolvendo a Junta ouropretana e aquelas Vilas mais próximas à Capital, interligadas pelo comércio e pela política à praça carioca, orientaram, em grande medida, a tendência de suas elites em aproximarem-se do poder central na figura de D. Pedro, cujo investimento nos poderes locais acenava com a possibilidade de conciliação de um poder hegemônico instalado no Rio de Janeiro com a perpetuação do domínio daqueles proprietários nas suas localidades.

Entretanto, este não foi um processo linear, nem mesmo entre aquelas elites mais diretamente interessadas em impor restrições aos excessos de jurisdição do governo provincial, revelando antes uma solução negociada ${ }^{24}$, que comportara sentidos diversos. Assim, se por um lado a firmação da soberania de D. Pedro passava pelo seu reconhecimento como "Digno Sustentáculo do Sistema Constitucional"25, por outro, o sentido emprestado a esta legitimidade era ambíguo, refletindo ora uma noção mais contratual da relação entre sociedade e poder rea|26, ora o apego à tradição dinástica, ao costume e a uma concepção do poder própria ao Antigo Regime. 27.

Se esta era a situação observada no centro-sul de Minas, ao fixarmos aquelas Vilas mais distantes - quer da Capital mineira, quer do circuito Rio-Minas - evidenciaremos outros condicionantes do processo em curso, o qual se revelou suscetível aos ânimos de indivíduos que, sem necessariamente aderirem às Cortes ou ao Príncipe, esboçaram um autonomismo em outro nível. Tal situação justifica nosso especial interesse pela Vila de Paracatu, situada no longínquo noroeste mineiro e onde, 
aos proprietários contemplados por sua visita, a visita era, geralmente, regada por benfeitorias e outras intervenções sobre questões que afetavam diretamente os interesses dos proprietários -, mandando abrir estradas para viabilizar o comércio, fazendo concessão de terras, bem como mandando soltar escravos presos "sem legitima razão" -, sem contar ainda os agraciamentos com cargos e promoções. (Ver, respectivamente, os seguintes documentos: Coleção dos Ofícios que as Câmaras e mais autoridades da Provincia de Minas Gerais tem dirigido à Sua Alteza Real o Príncipe Regente do Brasil...", in: RAPM, 1909, vol. XIV, p.358; "Portaria", de 11 de Abril de 1822, in: : RAPM, ano de 1909, vol. XIV, p. 381; "Decreto"de 19 de Abril de 1822, por Estevão Ribeiro de Rezende, in: $R A P M$, ano 1909, vol. XIV, p. 405).

25

"Ofício de Pedro Gomes Nogueira, Coronel de Cavalaria de Sabará", de 9 de Abril de 1822, in: RAPM, ano de 1909, vol. XIV, p. 354.

\section{6}

"Câmara de São João Del Rei", 11 de março de 1822 in: As câmaras municipais e a independência, vol. 2, op. cit., pp. 324-326.

\section{7}

"Câmara de Barbacena", 28 de maio de 1822, in: As câmaras municipais e a independência, vol. 2, op. cit. pp. 31-36.

\section{8}

Sobre a criação da Vila e Comarca paracatuenses, bem como os fluxos migratórios internos que deram origem à ocupação da região, ver, respectivamente: Oliveira Mello. As Minas Reveladas (Paracatu no Tempo). 2a. Ed., Paracatu: Prefeitura Municipal, 2002. p. 78; Renato Pinto Venâncio, "Paracatu: movimentos migratórios no século XVIII", in: Lócus: Revista de História. Juiz de Fora, vol. 4, n. 1, p. 85.

\section{9}

Olympio Gonzaga. Memória Histórica de Paracatu. Uberaba, 1910, p. 26.

\section{0}

"Movimento político em Paracatu (1822)", in: RAPM, ano de 1898, vol. III, pp. 288-290.

31

Neste sentido, a situação de Paracatu assemelha-se àquela verificada em algumas Vilas do Alto Sertão bahiano, onde também fez-se sentir a influência destes potentados locais, instaurando uma multiplicidade de poder no contexto da Independência: o Conselho Interino, instalado em Cachoeira, um Governo Provisório, na Vila de Rio das Contas, e fortes dissensões político-militares envolvendo autoridades da Vila de Caetité. Além da região ter contado com um processo de ocupação similar ao do Vale do São Francisco e noroeste mineiro - convergindo a pecuária, com a preação de índios e a busca de minas auríferas, não podendo a Coroa prescindir do poder das armas dos "senhores da terra" -, consolidara-se como a "principal via de comunicação para o São Francisco e uma rota quase obrigatória para os que desejassem chegar às Minas Gerais e a Goiás", desenvolvendo, em inícios do XIX, um intenso comércio interno e interprovincial, baseado na produção local de algodão e outros víveres. A nosso ver, as vias abertas pelo comércio propiciaram não apenas um perfil peculiar às suas elites - ligadas também por laços de parentesco - mas o intercâmbio de homens e idéias adensado em determinados momentos. Sobre este tema, bem como o processo similar de ocupação do noroeste mineiro, ver, respectivamente: Argemiro Ribeiro de Souza Filho, "A Guerra de Independência na Bahia: Manifestações políticas e violência na formação do Estado Nacional(Rio de Contas e Caetité)". UFBA, 2003 (Dissertação de Mestrado), e Bernardo Mata-Machado. História do Sertão Noroeste de Minas Gerais (1690-1930). Belo Horizonte: Imprensa Oficial, 1991. desde cedo, pesaram os vínculos comerciais, políticos e de parentesco com as províncias setentrionais da Bahia e Pernambuco, muito mais que com a própria Corte, ou a capital mineira. 28

Aí, o movimento da Independência fora marcado pelo autoritarismo de Antonio de Assis - sobrinho do influente Vigário Forâneo Joaquim de Mello Franco, que ocupara o cargo de Ouvidor da Comarca desde $1812^{29}$ - o qual, já na ocasião da eleição do Governo Provisório mineiro, procurara "com todo o empenho logo que chegaram aqui os Eleitores Paroquiais, inquietar os seus espíritos e movê-los a que se unissem para se Criar nesta Vila um Governo Provisório, no projeto de ser ele o Presidente, e com as suas seduções e convites particulares que fazia a alguns Oficiais de Milicias, ia causando uma grande revolução que felizmente se atalhou pela falta de união". Entretanto, seguindo denúncia do Ouvidor da Comarca Antonio Baptista da Costa Pinto ${ }^{30}$, mesmo depois de instalado o Governo Provisional e a notícia chegada à Vila de Paracatu, "ainda então aquele homem inquieto se atrevia a convidar os Eleitores (...) e aos Alferes José Carneiro, José Lopes, o Padre Miguel de Mello Chaves e o Capitão João Pereira da Costa (...) para nova Revolução, e Criação de novo Governo independente do legítimo(...)".

Descrito nestes termos, o movimento ocorrido em Paracatu sugere o peso das disputas patrocinadas pelos potentados locais no jogo político da independência, dimensão ainda pouco explorada pela historiografia e que, seguramente, influenciou a articulação da diversidade no forjamento da união ${ }^{31}$. Tendo seu poder pessoal e institucional questionado pelo constitucionalismo, os poderosos da terra, ou seus representantes imediatos, teceram alianças e externaram práticas políticas nuançadas por concepções de poder que remetiam a uma trajetória regional similar, ainda que nem sempre uniforme, com decisivas implicações na tessitura de vínculos identitários específicos e, por vezes, divergentes de um referencial tipicamente mineiro. ${ }^{32}$

\section{Se o enfoque a partir dos enquadramentos institucionais sob os} quais processou-se a ruptura luso-brasileira esgarça a recusa das elites mineiras aos diversos níveis de despotismo associados aos projetos alternativos ameaçadores das autonomias pretendidas, condicionando, em boa medida, a acomodação ao arranjo político arquitetado pelo poder central, vale lembrar que esta foi uma alternativa simultaneamente informada pela recusa a um outro sentido de alteridade fundamental aos sujeitos em causa: o "risco da anarquia", expressão que aludia às camadas desajustadas econômica e socialmente - "os infinitos vadios, homens brancos, mestiços, pardos cabras e crioulos forros"33 - associadas aos temores de uma sublevação escrava.

Embora o "medo" das elites a este respeito não fosse recente, adensava-se no contexto da independência, quer pela disseminação dos princípios liberais, quer pela fragmentação da autoridade decorrente da cisão entre os setores dominantes ${ }^{34}$ - levando-os mesmo a patrocinarem a ação de cativos e forros contra seus oponentes políticos -, quer ainda pela freqüente e perigosa associação entre estes últimos segmentos, em virtude da tenuidade dos laços que os separavam. 35 
Neste sentido, acreditamos ser mais proficuo pensa o regionalismo como um enfoque interpretativo de relações políticas entre centros de poder não previamente delimitados por fronteiras territoriais e políticas, mas como espaço de atuação e identificação das elites estudadas, resultante de sua própria ação política e econômica que extrapola tais limites e cuja dinâmica não, necessariamente, coincide com a do estado nacional. A este respeito, ver as reflexões de Vera Alice Cardoso Silva, "Regionalismo: o enfoque Metodológico e a concepção histórica", in Marcos A. da Silva (coord.), República em Migalhas. História Regional e local. São Paulo: Ed. Marco Zero, 1990, pp. 43-49.

33

"Carta Missiva de José Fernandes de Souza para o presidente da Assembléia Nacional, dirigida à Comissão do Ultramar, apresentando os vários pontos que haja necessidade de serem discutidos para o bem do povo daquela Comarca, de 15 de setembro de 1821. (BNRJ-Seção de Manuscritos, Avulsos do Conselho Ultramarino, Minas Gerais, mss 544, cx 188 , rolo 174 , doc 24 )

34

Sobre este tema, ver Carla M. J. Anastasia, Vassalos Rebeldes: violência coletiva nas Minas na primeira metade do século XVIII. Belo Horizonte: C/Arte, 1998.

35

Conforme relatamos em trabalho anterior, são inúmeras as tentativas de sublevação de escravos, associados a elementos livres e forros da população no contexto da independência. A este respeito, ver: Ana Rosa Cloclet da Silva, "Identidades Politicas e a emergência do novo Estado Nacional: o caso mineiro", in: István Jancsó (org.), Seminário Internacional Independência do Brasil: História e Historiografia, São Paulo: FFLCH/USP, de 06 a 12 de Setembro de 2003.

Este dilema, a nosso ver, explica a cautela que impunha o problema da "populaça", bem como o tratamento prescrito aos pardos, lucidamente formulado por Castro, ao apontar a inadequação da Constituição de Cádiz ao Brasil, no qual se refere aos critérios da representatividade política. ("Ofício do Governador D. Manuel de Portugal e Castro, examinado os Artigos da Constituição Espanhola que respeitam à formação das Cortes, das Juntas Eleitorais de Paróquia, Comarca e Provincia, com as Instruções dadas para a sua execução em Portugal e mandadas observar no Reino do Brasil pelo

Decreto de 7 de Março" de 1821, in: APM, Fundo Secretaria de Governo (SG), Avulsos, cx 121, pac. 22 , fls. $1-2$

37

Hebe Maria Mattos. Das Cores do Silêncio: o significado da liberdade no Sudeste escravista-Brasil séc. XIX. Rio de Janeiro: Nova Fronteira, 1998.

38

A necessidade de controlar e neutralizar a ação dos novos protagonistas condicionou a postura da própria Junta ouropretana, cujos membros, em Ofício de 19 de Fevereiro de 1822, predispunhamse a conciliar com o Vice-Presidente José Teixeira de Vasconcelos, em troca de auxilios destinados a aplacar "algumas perturbações" que pipocavam pela Província. Referiam-se, especificamente, aos fatos ocorridos no "Distrito de Minas Novas, nas Vilas de Principe e de Tamanduá", onde "tem-se notado vários ajuntamentos de negros, espalhando vozes da liberdade, e por tais motivos tem sido necessário socorrer estes lugares de mais Tropa do Regimento de Linha(...)".(As Juntas Governativas e a Independência, op. cit., p. 866).
Mais gritante, ainda, era a situação daqueles elementos intermediários, negros e mulatos, que já galgando conquistas materiais e ascendendo à condição de proprietários, passaram a pleitear, também, um lugar na esfera da representação política. A este problema, as elites dominantes não puderam ser alheias devendo, por um lado, forjar o seu equacionamento, do qual dependia a própria construção do consenso social em torno dos projetos alternativos por elas encampados; por outro, acomodar estas demandas preservando um senso de identidade fincado na distinção social e racial. 36

Dai o tratamento ambíguo que, muitas vezes, a questão recebeu, denunciando o verdadeiro esforço "reclassificador" desta camada intermediária, pela ótica das elites. De um lado, buscavam promover uma identificação de interesses com aqueles indivíduos, a partir de uma comum condição de proprietários, a qual, sobrepujando-se ao estigma da cor ${ }^{37}$, mostrava-se a via de acesso ao status de cidadão pleno em direitos e deveres; de outro, isolavam no extremo oposto aqueles segmentos que, não assimilados pelas novas atividades em expansão, permaneciam marginais às conquistas materiais e políticas abertas pelo constitucionalismo, representando permanente risco de radicalização do processo político em curso.

A nosso ver, este complexo contexto social das Minas da primeira metade dos oitocentos, avaliado segundo o interesse de afastamento simultâneo dos excessos de despotismo e dos riscos da anarquia, interferiu decisivamente nas articulações das elites contempladas entre si e com o poder central, selecionando as opções em jogo e definindo as possibilidades de conciliação e forjamento da unidade, no momento da formação do novo Estado nacional. 38

Do ponto de vista das formações identitárias em curso, portanto, vale insistir no argumento de que tais vínculos não se estabeleceram por uma positividade - por aquilo que as elites mineiras sabiam ser, ou pretendiam vir a ser-, mas antes pelos sentidos de "alteridade" destacados, os quais, ameaçando a propriedade e as hierarquias constituídas, desejavam neutralizar. Em outros termos, era por negação a ambas as possibilidades que, entre 1820-1822, aderiram à opção pela Monarquia Constitucional na figura de D. Pedro, reconhecendo-se como "brasileiros", termo que não excluia, num primeiro momento, o sentimento de pertencimento político à Grande família lusitana, mas que politizava-se pela adesão à "causa do Brasil", expressa na defesa da "paridade de direitos entre os Reinos" e, após Setembro de 1822, na adesão à Independência e unidade do novo Império Brasílico.

Adesão, contudo, duramente construída, matizada pelas clivagens de classe, vínculos étnicos e realidades materiais e sociais distintas que constituiam o espaço provincial, esgarçando as tensões entre localismos, poder regional e o centro político do novo Império, que persistiriam após 1822.

\section{II- A firmação da Monarquia Constitucional: certezas e incer- tezas da Nação}

Tal constatação desfaz idéia tradicionalmente consagrada por uma dada historiografia de que, ao verificar-se a Independência, "a Província está de tal modo vinculada a D. Pedro e ao processo emancipador que tudo 
"Felicitações pela coroação de V.M.I., pelo Desembargador Intendente Geral dos Diamantes, Manoel Caetano de Almeida e Albuquerque", Tejuco, 1823. (ANRJ, IJJ9, PAC 758).

\section{1}

"Oraçào Gratulatória que por ocasião do juramento da Constituição Brasiliense recitou no ato de sua solenidade na Imperial cidade de Ouro Preto e Capelados Terceiros do Carmoa 8 de abril do corrente ano o Vigário Antônio Franco Cônego da Rocha, Ex-Deputado por esta Província à Assembléia Geral do Império". Ouro Preto, 1824. (APM, SPPresidência de Província, cx 04, doc 03, p. 04).

\section{2}

"Termo de eleição dos sete membros de que deve compor-se o novo governo provisório nesta província de Minas Gerais, mandada fazer por S. Alteza Real o Príncipe Regente do Brasil, por portaria de 13 de Abril do corrente ano de 1823", in: RAPM, ano 1, fac. 1, 1896, pp. 101-113.

43

A demissão de Castro se dá logo após a aclamação de D. Pedro, por considerar-se "um dos obrigados a aproveitar-se do prazo de 30 dias que S. Majestade o Imperador Constitucional se Dignou Conceder no Decreto de 18 do referido mês", afirmando que "não podia conciliar novo comprometimento àquele pelo qual se achava ligado a Portugal".("Ofício do Governo Provisório para o Secretário do Estado dos Negócios do Reino", de15 de outubro de 1822, in: Correspondência oficial do Governo Provisório de Minas (1821-1824), op. cit., p. 627).

44

"Correspondência do Governo Provisório", de 29 de agosto de 1823, in: As Juntas Governativas e a Independência. Rio de Janeiro: Arquivo Nacional/ Conselho Federal de Cultura, 1973, p. 951.

45

"Correspondência do Governo Provisório", de 10 de Novembro de 1823, referindo-se às notícias de adesão do Maranhão e Pará, "desembaraçado da opressão e ingresso das Tropas Estrangeiras", in: As Juntas Governativas e a Independência, op. cit., p. 955.

\section{6}

"Registro de Ofício do Governo Provisório ao Ministério", sobre a dissoluçào da Assembléia Legislativa e sua repercussão em Minas Gerais, de 30 de Novembro de1823. (APM, SP 07, p. 223v)

47

idem.

48

"Correspondência do Governo Provisório", de 2 de Setembro de 1823, in: As Juntas Governativas e a Independência, op. cit., p. 952

\section{9}

Eram as seguintes suas atribuições: proceder os que cometem crimes no termo de sua jurisdição; ter alçada até a quantia de quatro mil-réis nos bens de raiz e de cinco mil nos móveis; ter alçada nas penas que puserem até mil-réis, sem apelação nem agravo; fiscalizar a atuação do alcaide-mor e alcaidespequenos e, após 1750 , ter alçada nos bens de raiz até 12 mil-réis, nos móveis até 16 mil e nas penas pecuniárias até quatro mi. (Graça Salgado (coord.). Fiscais e Meirinhos. A administração no Brasil Colonial. $2^{\text {a }}$. Ed., Rio de Janeiro: Nova Fronteira, 1985 , pp. 80, 261 e 359 ). se desenrola em paz" 39 . Na verdade, se aquele fato político imprimia nas elites mineiras a certeza do afastamento do projeto recolonizador - associado ao despotismo das Cortes lisboetas - não eram claros os caminhos a serem trilhados na sedimentação da condição de "Nação livre e independente" da "Gente Brasileira"40, na passagem do "vassalo" a "Cidadão", "de um povo colonial a uma Nação livre e independente" 41 , incertezas estas que tensionaram o ainda incipiente processo de regionalização do poder.

Neste sentido, é interessante fixar que, após o 7 de setembro de 1822, as divergências entre o segundo Governo Provisório - cujas eleições foram convocadas durante a primeira viagem de D. Pedro a Minas 42 - e o poder central atenuam-se, fato este reforçado com o afastamento de D. Manuel de Portugal e Castro, em 13 de outubro daquele ano 43. Expressavam, assim, a "mais rendida obediência" ao Imperador, dando "demonstrações de fidelidade, amor e patriotismo"44, regozijando-se pelas notícias de adesão das províncias do Norte e Nordeste à "Causa Geral do Império"45 e buscando imprimir a imagem de uma "boa harmonia entre os empregados públicos e as pessoas de qualquer classe" da província. 46

A própria dissolução da Assembléia Legislativa, em novembro de 1823, seria interpretada como um ato de heroísmo, de "firmeza e sabedoria com que S.M.I. (...) soube salvar o Império dos perigos que the estavam iminentes, Mandando convocar outra Assembléia para trabalhar sobre o Projeto de Constituição (...) a fim de que se consolide a união dos Habitantes deste Vasto Império", contando, por isso, com "toda a adesão, obediência e respeito" do Governo Provisório mineiro "à sagrada Pessoa do Mesmo Senhor"47.

\section{0 empenho em sedimentar tais sentimentos entre as diversas} Câmaras, contudo, já evidencia que a adesão não era unânime, como fica demonstrado pelo reconhecimento da "necessidade de se publicar aos Povos da Província a Proclamação em que Sua Majestade 0 Imperador Houve por bem patentear os firmes, puros e verdadeiramente Constitucionais Sentimentos de Seu Magnânimo Coração", justificado "por motivo de desenvolvimento de alguns princípios contrários à forma do Governo Monárquico-Constitucional". 48

Embora seja difícil penetrar a natureza destas tensões que instabilizaram a adesão à Monarquia Constitucional na província, neste momento, acreditamos ser possivel ao menos tangenciá-la, tomando como exemplos os casos mais freqüentes. Dentre estes, nota-se uma recusa de alguns habitantes das Vilas em manter subordinação àquelas autoridades diretamente vinculadas ao antigo sistema político, o que, num primeiro momento, recairá fortemente sobre os Juizes-de-Fora.

Criado no Brasil em 1696, este cargo era provido diretamente pelo rei, composto por funcionários letrados para servir nos municípios e, desde então, os mais importantes das Câmaras, refletindo o intento metropolitano de centralização administrativa e judicial ao nível das municipalidades 49 . Desse modo, as tensões entre estas autoridades e representantes da elite local, após 1822, refletem os próprios anseios destes últimos por autonomias, opondo-os a uma autoridade vista como despótica.

Era assim que, em Ofício para a Secretaria de Estado dos Negócios da Justiça, de novembro de 1822, o Governo Provisório anexava Representação dos povos da Vila do Bom Sucesso de Minas Novas, no 
50

"Ofício para a Secretaria de Estado dos Negócios da Justiça", de 9 de Novembro de 1822, in:

Correspondência Oficial do Governo Provisório de Minas (1821-1824), op. cit., p. 628.

51

0 caso é narrado em outro Ofício do Governo

Provisório, datado de 9 de dezembro de 1822, constando ter havido agravamento da situação na Vila de Minas Novas, ao ponto do referido Juiz ter sido "obrigado a retirar-se precipitadamente".(idem, p. 629 e 630).

\section{2}

"Ofício do Governo Provisório para o

Desembargo do Paço", de 18 de Julho de 1823, in: Correspondência do Governo Provisório (18211824),op.cit., p. 632-635. Tais circunstâncias, contudo, não deixariam de sustentar as propostas por uma maior autonomia da justiça, repercutindo nos debates travados na Câmara dos Deputados e pressionando no sentido da reforma do judiciário e elaboração de um novo Código Criminal, ocorrida em 1832.

53

Significativas, neste sentido, são as inúmeras queixas por usurpação de poder relatadas pelo Juiz de Fora José Gregório de Moraes Navarro, entre 1798 e 1812. ("Registro de cartas do Governador com vicereis, outros governadores e o Bispo". 1797-1809, in: APM, Seção Colonial, cx 278, p. 19v).

54

"Registro de Ofícios do Governo Provisório ao Ministério", de 28 de agosto de 1823, in: APM, SP 07, pp. 191v e 192.

\section{5}

Ofício do Governo Provisório de 27 de agosto de 1823, in: APM, SP 07, p. 191v.

56

Idem.

57

"Ofício do Governo Provisório" de 14 de outubro de 1823, in: APM, SP 07, p. 212. Segundo Olympio Gonzaga, a situação agitada em Paracatu era ainda reflexo das desavenças entre o ouvidor Antonio Baptista da Costa Pinto, e o Vigário Mello e seu sobrinho Francisco Assis, referido anteriormente, segundo Olympio Gonzaga, motivo pelo qual nomeou-se Limpo de Abreu para o referido cargo. (Olympio Gonzaga, op. cit., p. 28). Sobre a trajetória de Antonio Limpo Paulino de Abreu, o futuro Visconde de Abaeté, ver a obra de Bruno de Almeida Magalhães. $O$ Visconde de Abaeté. São Paulo/Rio de Janeiro/Recife/Porto Alegre: Companhia Editora Nacional, 1939

58

"Registro de Ofícios do Governo Provisório ao Ministério", de 2 de maio de 1823, in: APM, SP 07, p. 150v.

59

APM, PP1/30, Cx 2, "Ofícios de SMI ao governador das Armas da Provincia".

60

APM, CMP 11, pp. 171-172v. qual declaravam "seus desejos pela conservação do Juiz de Fora Caetano Ferraz Pinto", ameaçado na manutenção do cargo por alguns moradores da Vila, "afeitos a suplantarem as Autoridades ali constituidas e, especialmente aquelas que devem administrar a justiça, e que se acham na necessidade de soopear e reprimir seus caprichos e abusos, considerandose habilitados pelas novas idéias de liberalismo para procederem com toda a arbitrariedade que thes sugerissem suas paixões", cometendo o excesso de intimar-Ihe suspensão do Lugar".50

Perante as circunstâncias narradas, o próprio Juiz de Fora pedira seu afastamento, "embora não se houvesse completado o prazo de três anos", alegando que "de dia a dia se tornava mais precária a execução das Leis naquele Termo", contando, por mais de uma vez, com a interferência do Governo Provisório junto a S.M.I., para que assim se procedesse, entrando "logo no exercício o respectivo Sucessor"51. 0 poder regional buscava ainda seguir as provisões do Desembargo do Paço, "combinando as fontes e regras da Legislação, com os diferentes Regimentos, Provisões, e diferentes queixas das Câmaras e Juizes Ordinários, para se ver a moderação com que (...) sem denegar, nem tirar a algum o seu direito", pudesse "manter a ordem entre as autoridades constituídas com o repouso Público da Província. 52

0 caso não se esgotava à Vila de Minas Novas. Na Comarca paracatuense, os conflitos de jurisdição sempre marcaram a história política loca 53 , sendo atribuídos, numa correspondência do Governo Provisório de 1823, a uma administração composta por pessoas pouco "aptas para a governança, e quase nenhuma desligada de parentescos e afeições" 54 . Em função da situação ai reinante - marcada pela perseguição de alguns moradores por outros 55 -, o poder provincial manifestava em diversas Representações enviadas ao Imperador "a necessidade de um Ministro Letrado, que possa manter o devido equilibrio, e legal administração de justiça em tão longínqua e vasta Comarca, com quatro julgados nas suas extremidades, que cumpre estarem sujeitos a um Corregedor ativo e inteligente (...)".56

A solicitação seria atendida conforme Portaria expedida a 24 de setembro de 1823, participando "a nomeação do Bacharel Antônio Paulino Limpo de Abreu para aquele lugar vago há tempo"57. Entretanto, a política local continuaria sendo instabilizada, quer em função das disputas de poder entre os poderosos da terra, quer em função de outro elemento particularmente preocupante aos olhos dos membros do Governo Provisório: o fato da região gravitar, em grande medida, na órbita dos acontecimentos processados nas províncias limitrofes setentrionais, pondo em cheque a eficácia administrativa do poder regional e, em último caso, confirmando as incertezas sobre os rumos da Nação.

Era assim que, segundo informações do Marechal de Campo Governador das Armas de Minas Gerais remetidas ao Governo provisório, alertava-se para o risco de contaminação dos "Distritos limítrofes das Provincias da Bahia e Pernambuco" por ser constante, a presença de "bandos que vagam por aqueles Sertões"58. Perseguidos, estes "fascinorosos e salteadores" 59 - como eram descritos pelas autoridades - infiltravam-se no território mineiro, onde iriam mesclar-se à ação de outros grupos sociais marginalizados, não deixando de ser acoitados e ter suas ações igualmente instrumentalizadas por membros da elite local60, 
ibidem, pp. 170-171. Infiltrados no território mineiro principalmente via S. Romão e outros Julgados ao Norte da Comarca, a presença destes "desertores" da causa do Brasil reforça a necessidade de se buscar os aspectos tangiveis das rivalidades ai externadas nas lutas políticas travadas no Alto Sertão bahiano, marcadas pelas "investidas crescentes e audazes dos Mucunãs", grupos de homens livres pobres que vagavam pelo sertão bahiano perpetrando roubos e crimes, cujas demandas - que mesclavam aspectos de crise econômica, marginalização social, resistência ao recrutamento, embates políticos entre portugueses e homens da terra e insubordinação militar - e o próprio código de conduta - marcado pela violência -, foram patrocinados pelos potentados locais. (Argemiro Ribeiro de Souza Filho, op. cit. pp. 181-182).

64

Neste contexto, diversos Ofícios remetidos pela câmara paracatuense ao Governo Provisório informam sobre "a entrada disfarçada de emissários de Pernambuco", pelos Julgados que estão em contigüidade com aquela Província. Há mesmo informação sobre a prisão, em S. Romão, de "várias pessoas compreendidas na infame revoluçãodo Ceará". (Ver, respectivamente, APM, CMP 11, p. 49v (14/07/1824) e p. 11, (01/abril/1825))

65

"Ofício para a Secretaria de Estado dos Negócios do Reino e Estrangeiros", in: Correspondência do Governo Provisório (1821-1824), op. cit., pp. 613620.

\section{6}

"Ofício do Governo Provisório de 19 de dezembro de 1823", in: As Juntas Governativas e a Independência, op. cit., pp. 959-960. Persiste a dúvida da Câmara de Ouro Preto sobre mesmo tema, conforme Ofício dirigido ao Governo Provisório, em 19 de dezembro de 1823, in: APM, SP 07,p. 229

\section{7}

A circular de 17 de setembro de 1822, subordinando a Aclamação ao juramento prévio da Constituição, pelo Príncipe, representara uma vitória do que a historiografia convencionou designar como "partido Democrático", representado por José Clemente Pereira, presidente do Senado da Câmara. (Tobias Monteiro. História do Império. A Elaboração da Independência. T. 2, Belo Horizonte/São Paulo: Itatiaia/Edusp, 1981, pp. 635-637).

\section{8}

"Ofício da Câmara de Baependi", a 26 de janeiro de 1823, in: As Câmaras Municipais e a Independência op. cit., p. 51

69

'Ofício da Câmara de Barbacena", de 20 de janeiro de 1823, in: As Câmaras Municipais e a Independência, op. cit., p. 51. propagando "doutrinas revolucionárias"61 e insuflando as rivalidades entre "brasileiros"e "europeus"62, bem como o desrespeito às autoridades locais63. A situação se perpetuará durante todo o Primeiro Reinado, agravando-se no contexto da Confederação do Equador. ${ }^{64}$

Por fim, vale ressaltar que, mesmo entre aquelas Vilas mais próximas à Capital mineira, incluindo aqui a própria Imperial Cidade de Ouro Preto, a firmação da Monarquia Constitucional mostrou-se suscetivel às tensões e incertezas que permearam a montagem de um espaço público do poder regional. Do próprio Governo Provisório partiam freqüentes pedidos de esclarecimento acerca de suas efetivas atribuições, como aquele emitido já no contexto da viagem pedrina a Província, em abril de 1822, constando nada menos de 26 itens ${ }^{65}$. Em outros casos, encaminhava as dúvidas das Câmaras acerca de como proceder no novo contexto, conforme registrado em Ofício de 15 de Dezembro de 1823, referindose à hesitação da Câmara de Ouro Preto em festejar, conforme Provisão do Desembargo do Paço de 4 de abril de 1816, "o Aniversário do dia em que Sua Majestade Fidelísssima, por Carta de Lei de 16 de dezembro de 1815, elevou o Brasil à Categoria de Reino, porém unido ao de Portugal e Algarves", por parecer-Ihe tal ato "incompativel e contrário ao sistema adotado pelo Brasil". 66

A falta de clareza acerca das atribuições de poder, formas de procedimento e ao próprio significado do novo contexto constitucional levava, muitas vezes, a atitudes contraditórias com a própria manifestação da adesão aos princípios constitucionais, conforme evidenciado pela polêmica acerca da imposição ao Imperador do juramento prévio "de guardar, manter e defender a Constituição que fizesse a Assembléia Geral Constituinte e Legislativa do Brasil". Sobre tal questão, diversas Câmaras que já haviam inserido na Ata de Aclamação de D. Pedro a referida cláusula - atendendo ao Ofício do Senado da Corte, de 17 de setembro de 182267, "por confiarem então nimiamente na Constitucionalidade e boa fé daquele Senado" -, reconhecem ter sido este "um erro", passivel de ofender a Constitucionalidade de Sua Majestade Imperial"68.

A tal respeito, provinha da Câmara de Barbacena a mais completa indignação, pois que "além do que Sua Majestade Imperial se tem declarado o Protetor da Constituição, não se deve alguma Constituição humana um sacrifício que só é devido à palavra Divina. As Constituições humanas ainda que provenham de uma Autoridade legítima; ou são justas, ou são injustas: se justas, obrigam por direito natural e divino; se injustas a ninguém obrigam". E quanto a julgar sobre tal critério, acrescentavam ser esta uma atribuição que apenas competia às "Cortes Unidas" que, "depois de maduras reflexões sobre as circunstâncias que afetam este vasto Império, unirão como conveniente os dois pontos desta Cadeia".69

Entretanto, se o acatamento a tal cláusula por algumas Vilas mineiras refletia a tentativa de precaver-se contra uma possivel guinada absolutista do Imperador, ao reconhecerem tal "erro" não tinham em mente apenas seu potencial em ferir a "Constitucionalidade" do mesmo, mas, conforme registrado no Livro dos Acórdãos da Câmara de Queluz, os "horrores" em que "pode ser submergida esta grande Região pelas 
"Livro de Acórdãos da Câmara de Queluz", aos 26 de fevereiro de 1823, in: As Câmaras Municipais e a Independência, op. cit., p. 121

\section{1}

Tobias Monteiro, op. cit., p. 636.

72

As Câmaras Municipais e a Independência, op. cit. p. 206.

73

Idem, p. 56.
74

"Proclamação aos Habitantes do Brasil", in: D. Pedro I. Proclamações, Cartas, Artigos de Imprensa. Rio de Janeiro: GB, 1972, pp. 177-178.

75

Coleção das Leis do Império do Brasil. Rio de Janeiro, Imprensa Nacional, 1887, 2 partes. No Art. 3, do ano de 1823, lê-se: "0 Presidente será o executor e administrador da Província, e como tal estritamente responsável: será da nomeação do Imperador, e amovivel, quando o julgar conveniente".

\section{6}

Seguia-se, aqui, o mesmo procedimento das eleições para Deputados à Assembléia: "indiretas, elegendo a massa dos cidadãos ativos em Assembléias Paroquiais os eleitores de Província, e estes, os Representantes da Nação e Província".("Capitulo VI- Das Eleições", in: Octaciano Nogueira (org.) Constituições Brasileiras: 1824. 2a. Ed., Brasilia: Senado Federal e Ministério da Ciência e Tecnologia, Cento de Estudos Estratégicos, 2001, p. 91).

77

Coleção das Leis do Império do Brasil, op. cit., Art. 10.

78

Francisco Iglesias, op. cit., pp. 387-388.

79

Esta confirmava, em seu Art. 165, do Capítulo "Da Administração", o cargo de Presidente e, no seu Art. 71, do Capítulo V - "Dos Conselhos Gerais de Província e Suas Atribuições", ampliava o número de membros do Conselho para 21, naquelas províncias mais populosas, como era o caso de Minas. (Constituições Brasileiras: 1824, op. cit., pp. 88-90 e 101)

80

Coleção das Leis do Império do Brasil, ano de 1823, op. cit., Art. 24

81

Idem, Art. 30, 31 e 33.

82

Constituições Brasileiras: 1824, "Capítulo V", op. cit. pp. 88-90.

83

"Lei de 27 de Agosto de 1828. Dá Regimento para os Conselhos Gerais da Província", in: Coleção das Leis do Império do Brasil de 1828. Rio de Janeiro, Imprensa Nacional, 1887, Parte Primeira.: Atos do Poder Legislativo. conseqüências, que os malvados podem deduzir para seus perversos e anárquicos fins"70. Tratava-se, mais uma vez, de descartar ambos os extremos - a Anarquia e o Despotismo -, denunciando o instável sentido da adesão ao Imperador e à Constituição, acima referido.

Em suma, podemos dizer que a polêmica acerca do juramento prévio, assim como as diversas ordens de tensões que procuramos identificar neste curto periodo de 1822 a 1824, refletiam o próprio "estado de desconfiança e incerteza em que estavam" algumas Vilas, "sobre a fórmula de governo que se adotaria"71 e sobre os próprios rumos da Nação, expresso na ambígua convivência de referenciais políticos alternativos, que ora remetiam ao "Reino", ora ao "Império"72, ora ainda a um "Sistema Americano", cuja única precisão era opor-se "Sistema Europeu".73

Neste sentido, revelava-se a fragilidade da adesão ao projeto de Estado arquitetado pelo poder central, sempre prestes a romper-se e, do ponto de vista das elites mineiras aqui estudadas, sustentada enquanto perdurou a crença no sentido da Constitucionalidade que o próprio Imperador imputava-se: aquela que "sempre aparecerá triunfante qual Sol dissipando o mais espesso nevoeiro", sob a qual "vereis a Democracia e o Despotismo agrilhoados por uma justa liberdade". 74

\section{III- 0 "tempo-espaço" da modernidade política mineira}

As Juntas de Governo estenderam-se até 20 de outubro de 1823, quando D. Pedro sancionou a indicação da Assembléia Constituinte da Lei que dava nova forma aos governos das províncias, a partir de então confiados a um presidente - nomeado pelo Imperador, que poderia removê- $10^{75}$ - e a um Conselho - com caráter eletivo ${ }^{76}$, não permanente $e_{1}$ inicialmente, composto por 6 membros $^{77}$. No caso de Minas, porém, as Juntas funcionariam até fevereiro do ano seguinte, quando o primeiro presidente - José Teixeira da Fonseca Vasconcelos - seria empossado, permanecendo no cargo até 19 de março de 182778 .

Essa determinação, em caráter provisório, pouco alterou-se com a Constituição de 25 de março de 182479. Da competência do Presidente, continuaram sendo "todos os objetos, que demandem exame e juizo administrativo"80 - incluindo as determinações sobre o emprego da Força Armada "contra os inimigos internos" e "fora do Distrito"81 e as Ordenanças -, estando porém independente a administração da Justiça. Ao Conselho, competiria "propor, discutir e deliberar sobre os negócios mais interessantes das suas Províncias; formando projetos peculiares e acomodados às suas localidades e urgências", discutindo "a portas abertas" os "negócios que começarem nas Câmaras" e remetendo suas "Resoluções (...) diretamente ao Poder Executivo, pelo intermédio do Presidente da Província", para serem oportunamente enviadas pela respectiva Secretaria de Estado à Assembléia Geral, como "Projetos de Lei", ou, quando a mesma não estiver reunida, recebendo direta resposta do Imperador. ${ }^{82}$

Contudo, o método de prosseguirem os Conselhos Gerais de Província em seus trabalhos, e sua polícia interna e externa não ficaram determinados, nem na Lei de 20 de outubro de 1823, nem na Constituição de 1824, a qual previa um Regimento, "que Ihes será dado pela Assembléia Geral", e que só viria a se concretizar em 182883. Efetivamente, é a partir deste ano que os trabalhos dos Conselhos se encontram 
A primeira reunião do Conselho ocorre em 6 de junho de 1825, já com algum atraso e com a participação de suplentes, devido a dificuldade de reunir seus membros, o que, diga-se de passagem, será uma constante nos trabalhos do órgão.

\section{5}

Fonte fundamental para tal acompanhamento são os Diários do Conselho Geral de Província - 1828 a 1833, APM, microfilmado, rolo 20. Além desta documentação, estaremos recorrendo aos documentos pertencentes ao Fundo Presidência de Província (PP) e Câmaras Municipais (CMOP e CMP), pertencentes ao APM, bem como aos "Relatórios dos Presidentes da Província ao Conselho Geral, de 1828 a 1833", in: RAPM, vol. XVIII, 1912, pp. 97 a 113.

\section{6}

A investigação é relevante visto que, apesar de muitos autores debruçarem-se sobre a temática da centralização/descentralização durante o período regencial, persistindo ainda grande silêncio sobre este processo, durante o Primeiro Reinado. Sobre o tema, ver as contribuições de José Murilo de Carvalho, Teatro de sombras: a politica imperial. São Paulo/Rio de Janeiro: Vértice/Ed. Revista dos Tribunais, 1988, e; Ilmar R. Mattos. 0 tempo Saquarema: a formação do Estado Imperial. Rio de Janeiro: Access, 1994

\section{7}

A região denominada "Metalúrgica-Mantiqueira", corresponde ao núcleo minerador original da anterior capitania, onde estavam localizadas a Capital Ouro Preto, a sede do bispado mineiro, Mariana, e os dois mais importantes entrepostos comerciais das Minas na primeira metade dos oitocentos: São João Del-Rei e Barbacena, constituindo-se na mais populosa e urbanizada, contando com um dinâmico comércio de abastecimento interno e, principalmente, articulado à praça carioca. (Douglas Cole Libby. Transformação e Trabalho em uma economia escravista. São Paulo: Brasiliense, 1988, p. 32).

88

Wlamir Silva, op. cit, pp. 133 e segs. Para o periodo que nos interessa, vale destacar: em Ouro Preto, 0 Novo Argos (editado entre 1829 e 1834); em São João Del Rei, 0 Astro de Minas (que circulou entre 1827 e 1839) e o Mentor das Brasileiras (entre 1829-1832); ao Norte de Minas, $O$ Echo do Serro (1828); no Arraial do Tejuco, O Sentinela do Serro (1827-1832). De tendência "conservadora", detacou-se, ainda em Ouro Preto, 0 Telégrafo, principal oponente do Universal. Estes periódicos se encontram microfilmados na Seção de Obras Raras da Biblioteca Nacional do Rio de Janeiro.

\section{9}

Wlamir Silva, op. cit., p. 137

\section{0}

Ver alguns "Código de Posturas" das Câmaras de Ouro Preto, Mariana, Queluz, in: "Atas do Conselho Geral da Província de Minas Gerais- 1828 a 1833", in: APM, rolo 20.

91

0 Conselho compunha-se de duas comissões permanentes; uma para o exame das representações das Câmaras, e outra para inspeção, e polícia da casa, podendo haver escolha de comissões especiais, quando o Conselho decidir ser convenientes. Para tanto, era necessário haver demanda "e que a petição depois de apoiada por três Conselheiros pelo menos, seja deferida por voto do Conselho". Não poderia compor-se por "menos de três membros, nem de mais de cinco", formando-se por "membros do Conselho, nomeados à pluralidade relativa, por escrutínio secreto", dentre os quais não poderia constar "o Presidente, e o Secretário".("Lei de 27 de Agosto de 1828. Dá Regimento para os mais organizados 84 , permitindo-nos um acompanhamento mais sistemático dos assuntos discutidos em suas sessões. 85

Ainda que a forma definitiva deste processo de regionalização do poder só viesse a se concretizar com o Ato Adicional de 1834 - que criava as Assembléias Legislativas provinciais - podemos visualizar, já neste primeiro momento da atuação do Presidente e Conselho de província, a natureza dos embates que marcaram a passagem de vários esboços nacionais, - elaborados em nivel regional e mesmo local, sob forte influência dos anseios por relativa autonomia administrativa de suas elites - para a construção de uma única nação, sob a égide do Estado, o que envolvia certo grau de centralização política e administrativa. ${ }^{86}$

De antemão, vale lembrar que o clima político da província não pode ter como termômetro apenas as instâncias de poder assinaladas, na medida em que este é o momento por excelência do periodismo mineiro como veículo formador da opinião pública e, especialmente, da imprensa liberal moderada, através da qual as elites da região Metalúrgica-Mantiqueira 87 exerceram uma verdadeira "relação pedagógica" com a incipiente sociedade civil das Minas - buscando construir o consenso em torno de seu projeto de Estado -, bem como um novo canal de "contigüidade" com a Corte do Rio de Janeiro, já precedida pelas conexões comerciais e políticas $^{88}$. Neste sentido, destaca-se 0 Universal, periódico editado em Ouro Preto entre 1825-1842, representando o pensamento liberal-moderado em gestação e marcando o "panorama cultural" mineiro. 89

Em exercício, o Conselho de Governo tratou das questões do interesse da Província, analisando e alterando as Posturas das Câmaras municipais 90 , examinando as Representações por estas enviadas, através de uma Comissão permanente ${ }^{91}$, arbitrando sobre os assuntos de sua alçada ou encaminhando as decisões ao Presidente da Província, que tinha o poder de despachar por si só e decidir todos os negócios, em que o Regimento de 1828 não exigisse especificamente a cooperação do Conselho. ${ }^{92}$

Coerente com as expectativas de benefícios localizados, externadas pelas elites mineiras durante todo este processo de crise do antigo sistema e construção do novo Estado, sobressaíam dentre os assuntos tratados as realizações materiais diretamente conectadas à prosperidade econômica e intelectual da Província e aos propósitos de suas Vilas e localidades específicas, apresentadas, desde então, como os ícones da modernidade política, da entrada na civilização, enfim, do definitivo rompimento com a situação colonial, pois, conforme veicularia 0 Universal por ocasião das comemorações do 7 de setembro: "a Independência será eterna. Resta pois consolidar a Liberdade".93

Já no Relatório do Presidente da Província, lido na instalação da primeira legislatura do Conselho Geral, em 1828, depositava-se na nova forma administrativa as "esperanças de progresso rápido" da "mais rica, a mais bela das Províncias do Império", cujo "estado atual irá ascendentemente a melhor". Para tanto, relatava-se como os objetos a exigirem providências - sempre guiadas pelo "saber, Patriotismo e Zelo do Conselho" - as "rendas públicas, administração, justiça, estradas, pontes, agricultura, indústria e sobretudo Instrução pública, porque ela abrange tudo". 94 
Conselhos Gerais de Província", Título V - "Das Comissões' - Art. 71 a 75, in: Coleção das Leis do Império do Brasil de 1828, op. cit.)

92

"Lei de 20 de Agosto de 1823", Art. 8 e 26.in: Coleção das Leis do Império do Brasil, op. cit. 93

O Universal, n. 483, 20 de Agosto de 1830.

\section{4}

"Relatório do Presidente João José Lopes Mendes Ribeiro", 1828, in: RAPM, vol. XVIII, 1912, p. 97-99.

95

Deste trabalho eram encarregados os Ouvidores de Comarca. ("Lei de 20 de outubro de 1823", in: Coleção das Leis do Império do Brasil, Art. 24, n. 7º.).

\section{6}

"Ata da Câmara Municipal de Ouro Preto, sessão de 16 de abril de 1830, in: APM, CMOP, códice 244, pp. $17 v$ e 18 . Tendo em vista a relevância do tema, a Câmara propunha a nomeação de uma comissão especial para avaliar sobre um plano geral de estradas, a ser elaborado por Engenheiro competente.

97

"Parecer do Fiscal José Pedro de Carvalho, respondendo a despacho da Câmara Municipal de Ouro Preto de 26 do corrente, ordenando que informasse se a obra que pretendem os moradores da Ponte do Rosário". (APM, CMOP, códice 244, cx 2, doc 26).

98

Sobre tal tendência, ver parecer do Presidente José Lopes Mendes Ribeiro, de 1828, favorável à abertura de uma estrada "que segue para essa Corte pelo Mar de Espanha, onde já há um Registro". ("Correspondência de José Lopes Mendes Ribeiro", para a Intendência Geral de Polícia, a 28 de janeiro de 1828, in: RAPM, ano IX, fac. III e IV, jul-Dez. 1904, pp. 689-690).

99

A situação se evidencia quando do parecer do segundo Governo Provisório acerca do melhor local para instalação de uma fábrica de Armas na província, indicado como sendo a Imperial Cidade de Ouro Preto. ("Ofício do Governo Provisório para a Secretaria do Estado dos Negócios da Guerra", de 28 de Agosto de 1823, in: Diversos Registros da Correspondência Oficial da Presidência de Minas 1827-1829, RAPM, op. cit., pp. 635-638).

\section{0}

"Relatório do presidente Marechal José Manoel de Almeida", 5 de dezembro de 1830, op. cit., p. 100.

101

"Parecer do Fiscal José Pedro de Carvalho sobre a Estrada que vai para a Casa da Pedra", de 28/03/1829, in: APM, CMOP, códice 244, cx 2, doc 27.

102

"Câmara de Ouro Preto", sessão de 05/09/1829 (APM, CMOP, códice, 244, doc. 64).

103

Apenas em 1835, a Assembléia Legislativa de Minas Gerais criaria o cargo de Inspetor Geral das Estradas e três engenheiros para traçar um plano geral de estradas da província.
A grosso modo, podemos dizer que as temáticas apontadas pelo então Presidente Lopes Mendes Ribeiro foram reprisadas nos Relatórios seguintes, até o ano de 1831, bem como nas sessões do Conselho, refletindo a necessidade do poder regional de conhecer o espaço público sob sua jurisdição e a população que o habitava - já que a Lei de 20 de Outubro de 1823 incumbia-o de "formar o censo e estatística da província", remetendo o resultado à Assembléia Constituinte ${ }^{95}$-, para conseguir manter a ordem e difundir a prosperidade almejada. Uma leitura atenta destas fontes, por sua vez, torna flagrante a centralidade assumida pelos seguintes objetos: promoção da instrução pública - pela razão acima ponderada -, obras públicas - destacando-se aquelas relacionadas à viabilização do comércio e abastecimento da província - e manutenção da ordem/segurança, temática associada aos freqüentes problemas de jurisdição e à insubordinação das classes subalternas.

É interessante confrontar o modo como estas questões foram abordadas e encaminhadas pelas esferas de poder regional e local, a fim de identificarmos possiveis tensões em seu relacionamento. Assim, fixando a documentação camarária ouropretana, nota-se a evidência conferida ao problema da "conservação das Estradas da Província", bem como o reparo de "Pontes" e "caminhos" que viabilizassem o comércio, objeto que, sem a devida atenção, imporia à Província "toda a sorte de privações, e até fome", emperrando a própria "civilização".96

A questão se reprisa em outros documentos, sendo interessante recorrer aos Relatórios dos Fiscais encarregados da inspeção das obras públicas - onde expunham o estado das diferentes obras, incluindo instrução pública, saneamento, prisões e hospitais - bem como aos seus Pareceres sobre aquelas propostas pelas Câmaras. Neste último caso, ficava evidente a impossibilidade em discernir-se o que "era de interesse público ou meramente particular"97, inviabilizando um tratamento dicotômico da questão e, neste sentido, esgarçando os próprios limites da autonomia do novo Estado, cuja legitimidade revelava-se profundamente dependente do apoio de grupos privados específicos.

À necessidade de equacionar estes diferentes interesses, agregavase outra dificuldade, relacionada à tendência em haver uma concentração espacial das obras naquelas Vilas mais próximas à capital mineira, economicamente mais prósperas e politicamente mais influentes ${ }^{98}$. 0 fato é recorrente em outras realizações materiais, caracterizando também a atuação do antigo Governo Provisório99, o que sugere não só a maior capacidade de barganha das elites próximas ao poder provincial - cujos representantes estavam diretamente em contato com as demandas de suas localidades -, mas o próprio empenho dos Presidentes em viabilizarem empreendimentos que não fugissem aos seus controles, pois imputavam à "extensão e dificuldades de comunicações" o mau conhecimento da "variedade dos objetos particulares" às partes mais distantes. ${ }^{100}$

Além dos interesses da "economia e das rendas Municipais"101 _ incluindo ainda o problema do abastecimento102 - a preocupação com a comunicação interna e interprovincial se justifica pela necessidade de viabilizar o bom funcionamento das instituições e leis que passavam a reger a vida política da província103. Expressivo da relação entre os temas eram os inúmeros casos de adiamento das sessões de instalação do Conselho de Estado, pela impossibilidade de seus membros compare- 
Diário do Conselho Geral da Província de Minas Gerais, ano de 1830, aos 06 de Dezembro de 1830, op. cit., p. 14

105

0 tema seria lucidamente exposto numa fala do futuro Presidente Limpo de Abreu, em sessão da Assembléia Provincial, no ano de 1835, a propósito da maior atenção que deveria merecer o péssimo estado das "estradas", pois: "em um pais como o nosso, onde as instituições e as leis ordenam o comparecimento de cidadãos, para preencherem tão multiplicados, e variados deveres, o serviço público não pode deixar de padecer". (Apud, Márcio Eurélio Rios de Carvalho, op. cit., p. 104.)

106

Bernardo Pereira de Vasconcelos, Carta aos eleitores da província de Minas Gerais,dezembro de 1827 in: José Murilo de Carvalho (org.). Bernardo Pereira de Vasconcelos. São Paulo: Ed. 34, 1999, p. 93.

107

Idem.

108

"Lei de $1^{\circ}$. de Outubro de 1828. Dá nova forma às Câmaras Municipais, Marca suas Atribuições, e o processo para a sua eleição, e dos Juizes de Paz", in: Coleção das Leis do Império do Brasil, op. cit., ano de 1828, Titulo III - Das Posturas Policiais -. Art. 66 e 72.

109

Exemplo significativo destes atritos apresentara-se no concernente às propostas apresentadas pela Câmara de Ouro Preto, no sentido de solucionar os freqüentes problemas de abastecimento e carestia de bens, estipulando os limites de preços para gêneros de primeira necessidade, lavradas em Sessão de 15 de Agosto de 1826. Apresentadas ao Conselho em Ofício de 27 do mesmo mês e ano, as Posturas seriam consideradas anticonstitucionais e revogadas. (APM, CMOP 3/5, Documentação interna/Documentação administrativa, cx 1, doc 52 01/12/1828; e CMOP 1/8,- Correspondência recebida/Força pública, cx 1, doc 64, 05/09/1829).

110

A este respeito, ver parecer da Comissão nomeada pela Câmara ouropretana "para o exame dos Hospitais e prisões desta Cidade", de 30/03/1829, in: APM, CMOP, códice 244, cx 2, Doc 30

111

"Regulamento de providências policiais, a respeito de escravos e Taverneiros". Ouro Preto: Officina Patrícia de Barbosa, 12 de agosto de 1825, in: APM: PP3/01, cx 1, doc 1 .

112

Outras medidas gerais eram voltadas para a solução do problema, como as "rondas noturnas", estabelecidas pelas Câmaras.(APM, CMOP 3/5- CX 05, Doc $55,(26 / 04 / 1830)$

113

Atas do Conselho Geral da Província de Minas Gerais, Ano 1828, APM, ROLO 20, pp. 12 e 22.

114

"Código de Posturas da Câmara Municipal de Ouro Preto - Título 4. Da segurança Pública, Cap. 1", in: Atas do Conselho de Estado, ano de 1828, pp. 19 e 20

115

O Universal, n. 238, 22/01/1827. Neste número, "0 Sertanejo", escrevendo de Minas Novas, denunciava que apesar das leis e providências policiais contra Taverneiros e Escravos, nada se tem executado.

116

0 enfoque não era recente, repousando nas considerações de Saavedra, acerca da necessidade de se "reformar valores e comportamentos", como forma de reverter a "decadência" da mineração. (Basílio Teixeira de Saavedra, "Informação da Capitania de cerem, mediante a ocorrência de chuvas, desmoronamentos de barreiras, ou outros incidentes que obstavam os caminhos 104 . 0 assunto teve longo fôlego ${ }^{105}$ e, a nosso ver, desnuda uma das dimensões da fragilidade de consolidação e funcionamento do poder público regional, como representativo dos interesses gerais da população da província.

0 reconhecimento destes entraves à consolidação de um espaço público nas Minas era manifesto por Bernardo Pereira de Vasconcelos, vendo aí o resultado "de exames feitos a grandes distâncias, e por quem nelas [nas obras] não tem interesse", impedindo-nos de abraçarmos "a prática das nações mais policiadas", exemplos de civilização, progresso e modernidade política106. Neste sentido, louvava a resolução da Assembléia Constituinte acerca da construção de obras como "pontes, calçadas, estradas, canais e outras semelhantes", que autorizava "à Câmaras para arrematar as dos seus respectivos termos, aos governos provinciais as das respectivas províncias, que abrange mais de um termo, e só à Assembléia o mandar fazer as que pertencessem a duas ou mais províncias, ou as que não tiveram arrematantes".107

No seu formato final, contudo, as leis acerca das Posturas municipais - que tinham a seu cargo os objetos de "alinhamento, limpeza, iluminação, e desempachamento das ruas, canais e praças, conservação e reparos de muralhas, feitas para segurança dos edifícios, e prisões públicas, calçadas, pontes, fontes, aquedutos, chafarizes, poços, tanques, e quaisquer outras construções em benefício comum dos habitantes, ou para decoro e ornamento das povoações", dentre outros - submetiam-nas a uma vigência temporária, apenas "por um ano, enquanto não forem confirmadas, a cujo fim serão levadas aos Conselhos Gerais, que também as poderão alterar, ou revogar"108. Este fato, agregado a outros elementos que discutiremos adiante, implicaria atritos entre os poderes locais e provincial, pois nem sempre as medidas propostas nas Posturas ganhariam aprovação definitiva do Conselho.109

A preocupação com as prisões e hospitais, por sua vez, conecta-se diretamente ao tema da segurança pública, sendo que, enquanto esta última relacionava-se à preservação da saúde pública - passivel de ser ameaçada pelo mau estado de conservação dos prédios que serviam de abrigo aos doentes ${ }^{110}$ - a primeira era condição imprescindivel para a regular aplicação da justiça e manutenção da ordem, aparecendo diretamente relacionada ao problema das "classes infimas". Neste sentido, já no início de seus trabalhos, o Conselho Geral da Província elaborou um Regulamento de providências policiais ${ }^{111}$, no qual dispunha, em 14 Artigos, diversas medidas para evitar ajuntamentos de escravos em tavernas, com riscos de desestabilização da ordem pública ${ }^{112}$. 0 problema, contudo, persistiria, registrando-se nas inúmeras queixas levadas ao Conselho através de Requerimentos provindos de diversas localidades ${ }^{113}$, nas Posturas camarárias, submetidas a exame e aprovação do Conselho ${ }^{114}$ e na imprensa liberal da Província ${ }^{115}$. Nestes documentos, fica patente 0 desconhecimento da lei pelos moradores, mesmos das Vilas mais próximas à Capital, e a difícil tarefa do Conselho em "alocar" os assuntos segundo as autoridades competentes, dimensionando aqueles de sua alçada.

Com relação aos "vadios", nota-se a preocupação em enquadrálos no "ideal de trabalho"116 - justificando as Posturas Municipais que proibiam "pedir esmolas, quando se pode com o trabalho adquirir meios 
Minas", de 30 de março de 1805. RAPM, 2:637-83, p. 675-677, apud,Marco Antonio Silveira, 0 universo do Indistinto. Estado e Sociedade nas Minas setecentistas (1835-1808), São Paulo: Hucitec, 1997, pp.74-75).

117

"Código de Posturas da Câmara Municipal de Ouro Preto, op. cit., p. 20.

118

Atas do Conselho Geral da Província de Minas Gerais, sessão de 26 de março de1828, op. cit., p. 57. 119

Compartilhamos, aqui, do diagnóstico de Márcio Eurélio Rios de Carvalho, para o período posterior a 1834.

120

0 controle da circulação escravos e libertos, estendido aos livres pobres, era prática corrente das autoridades mineiras, registrando-se na carta enviada pelo Governador Ataide e Mello a todos os capitãesmores da Capitania, com data de 14 de dezembro de 1807 , na qual determinava "que nenhum dos moradores, à exceção das pessoas estabelecidas conhecidas e de probidade,poderá sair do seu Termo, e passar para fora da Capitania,sem que leve uma guia, ou passaporte seu ou do Juíz Ordinário, ou Ministro onde o houver, ficando na inteligência que sem ele não dará passagem livre em quaisquer Registros, contagens ou guardas, que guarnecem os limites desta Capitania". (APM, SC, códice 315, p. 41).

121

"Portaria do Imperador comunicada pelo Governo provincial, de 11 de fevereiro de 1828", in: APM SP 54, pp. 74v e 75v. 0 mesmo procedimento pode ser identificado entre as elites e autoridades bahianas e cariocas, conforme estudo de Silvia $\mathrm{H}$. Lara, "Reminiscências setecentistas. Escravidão, Cultura e Poder na América Portuguesa". Campinas: Unicamp/IFCH, 2004. (Tese apresentada para o concurso de Livre-Docência).

122

Márcio Eurélio Rios de Carvalho, op. cit., p. 111.

123

"Relatório do Presidente João José Lopes Mendes Ribeiro", 1828, in: RAPM, vol. XVIII, 1912, p. 97-99. 124

Sobre estes percalços trazidos da fase colonial, ver Luiz Carlos Villalta, "Educação Pública e Educação Privada na América Portuguesa", in: Termo de Mariana. História e Documentação. Ouro Preto: Ed. da UFOP, 1998, p. 189. Especificamente sobre o ensino nas Minas Gerais, ver": Paulo Krüger Corrêa Mourão. O Ensino em Minas Gerais no Tempo do Império.Ouro Preto: Edição do Centro Regional de Pesquisa, 1959, p. 3.

125

Caio C. Boschi, A Universidade de Coimbra e a formação das elites mineiras coloniais. Estudos históricos. Rio de Janeiro, vol. 4, n. 7, 1991.

126

Pela Lei de 15 de outubro de 1827, a Assembléia Legislativa aprovava o projeto de Januário da Cunha Barbosa a respeito do tema, estipulando a criação de escolas primárias em todas as cidades, vilas e lugares mais populosos, introduzindo-se o "Método do Ensino Mútuo" ou "Lancasteriano", em que, numa estrutura hierarquizada, os alunos mais "proficientes" ensinariam os demais. Cabia ao Conselho Geral e ao Presidente da Província determinar acerca dos exames públicos, nos quais os alunos eram argüidos em gramática, geometria, aritmética, principios religiosos e políticos. (Wlamir Silva, op. cit., p. 182).

127

Bernardo Pereira de Vasconcelos, Carta aos Eleitores da Província de Minas Gerais, op. cit., p. 116.

128

É neste sentido que a Câmara de Caeté aprovava, em 1829, a criação de uma "casa de trabalho de subsistência"117 - não estando descartadas medidas que visavam seu confinamento e separação do corpo social, conforme denuncia o plano de construção de uma "casa de correção para vadios e ociosos", mencionado pelo Conselho Geral, em sessão de 1828. ${ }^{118}$

A grosso modo, podemos perceber nestas discussões acerca das obras prioritárias, direta ou indiretamente relacionadas à prosperidade econômica e segurança pública da província mineira, um marcado intuito em separar os "indivíduos probos" - sobretudo os envolvidos com o comércio e a administração pública -, dos "vadios, criminosos e desordeiros"119. Aos primeiros, buscava-se facilitar o trânsito e as atividades; aos segundos, reservava-se a reclusão e o controle ${ }^{120}$, sendo freqüentemente empurrados para uma comum condição de cativos - idéia esta reforçada pelo arraigado hábito de designá-los genericamente como "negros"121_, apartados de uma liberdade reservada aos elementos passiveis de configurarem na sociedade civil.

Esboçava-se assim, conjuntamente "ao desafio de compor e definir o espaço público provincial"122, um projeto civilizatório fortemente excludente, melhor dimensionado quando tomamos em conta a preocupação com a instrução pública, vislumbrada como estando "na razão direta da qual se promove a civilização, grandeza e opulência dos Estados".123

De dimensões ainda restritas, se comparada ao ensino privado, revelando carências de diversas ordens - de livros, professores e comunicação ${ }^{124}$ - e limitado alcance social mesmo entre os filhos das elites - que continuaram obtendo suas formações na Europa, sobretudo em Coimbra'125 - a instrução pública em Minas Gerais durante o Primeiro Reinado passaria à responsabilidade dos Presidentes de Província, auxiliados pelas Câmaras. ${ }^{126}$

A partir de então, a elite mais diretamente conectada ao centro político provincial e imperial veria na difusão da educação, alicerçada na liberdade de imprensa, um instrumento fundamental no exercício da sua pedagogia política e formação de uma opinião pública pautada nos princípios liberais, surgindo, segundo Bernardo Pereira de Vasconcellos, como o modo pelo qual "se poderão nivelar pouco mais ou menos as faculdades morais dos brasileiros e que se aniquilará essa dependência real que as luzes de uma classe exerciam sobre a cega ignorância da totalidade; dependência que tanto contribuira para a consolidação do cetro de ferro que por três séculos nos oprimiu".127

Há, porém, que se atentar para os limites desta proposta liberal concernente à instrução, a qual, como qualquer outra veiculada pelas elites mineiras naquele momento, vinha crivada de forte sentido hierárquico, o que implicava diferentes formas e graus de incorporação à modernidade política, segundo as distintas condições de proprietários e "despossuídos"128, gradações de cores e diferença de sexo.129

Outros, ainda, seriam os entraves à sedimentação deste projeto civilizatório. No Relatório do Presidente de Minas Gerais, de 1830, aludindo à situação da "educação da mocidade", a partir de dados relativos ao ano de 1826, registrava-se a predominância do ensino privado, bem como uma marcada concentração regional dos estabelecimentos, naquelas Vilas próximas à Capital mineira, ou articuladas ao eixoRio-Minas ${ }^{130}$, o que era fruto do direcionamento dado pelos próprios Presidentes da Província ao assunto. ${ }^{131}$ 
para os pobres robustos de ambos os sexos", para "extirpar o vício da ociosidade que tanto pesa sobre as classes industriosas". (O Universal. N. 319, 29/07/1829)

\section{9}

APM, CMOP 3/5 (Documentação interna/

Documentação administrativa), Cx 2, docs.: 32, 34, $36,39,54$ e 63

130

"Relatório do presidente Marechal José Manoel de Almeida", ao Conselho Geral, 5 de dezembro de 1830, in: RAPM, vol. XVIII, 1912, p.102.

131

Em duas correspondências enviadas à Secretaria de Estado dos Negócios do Império, no ano de 1828, o então presidente João José Lopes Mendes Ribeiro recomendava como melhor lugar para a instalação de um "Colégio de Estudos menores" e de "Escolas de 1as. Letras", respectivamente, a Imperial Cidade de Ouro Preto e a de São João Del Rei. ("Correspondência do Presidente João José Lopes Mendes Ribeiro, à Secretaria de Estado dos Negócios do Império", respectivamente aos 30 e 31 de março de 1828, in: RAPM, ano IX, fac. III e IV, julDez. 1904, pp. 691-692 e 693).

132

No supracitado Relatório Mendes Ribeiro referiase às "Aulas de Anatomia, de Arte Obstetricia, de Desenho, de Gramática latina, de Filosofia Racional e Moral, e de Retórica", já instaladas em Ouro Preto. 133

"Discurso na Câmara dos Deputados, sessão de 7 de Agosto de 1826", in: José Murilo de Carvalho (org.) op. cit., pp. 42-43.

134

Marco Morel, La gênisis de la opinión pública moderna y el proceso de independência, op. cit., p. 300-301.

135

Luiz Carlos Villalta, "0 que se Fala e o Que se Lê: língual, instrução e leitura", in: Laura de Mello e Souza (org.), História da vida privada no Brasil. São Paulo: Cia das Letras, 1997, vol. 1, p. 373-374.

136

Assim, do mesmo modo que 0 Universal comunicava com entusiasmo o estabelecimento de um gabinete de leitura na Casa do Padre Antônio José Ribeiro Bhering, em, fevereiro de 1830, que franqueava aos interessados periódicos paulistas, cariocas e mineiros, a população de S. João Del Rei aterrorizava-se mediante a reunião de indivíduos

"de pouco afetos ao sistema constitucional (...) em casa do Coronel Antonio Constantino de Oliveira", cujo teor, não se podendo tomar conhecimento "porque a Lei não permite violar a casa do Cidadão a horas da noite", só veio a lume no dia seguinte, quando editaram-se dois impressos, nos quais os "verdadeiros constitucionais" da Vila eram apregoados de "desorganizadores e federalistas". 0 fato merece atenção pois ilustra a própria ambigüidade da lei, num contexto onde o projeto liberal moderado esteve longe de ser consensual. (0 Universal, n. 398 (01/02/1830): "Correspondência do Juiz de Paz Martiniano Severo de Barros, ao Presidente da Provincia, de 31 de março de 1831", in: APM,PP1/33, cx 270, doc 53).

137

"Carta aos senhores eleitores da Província de Minas Gerais", dezembro de 1827, in: José Murilo de Carvalho (org.), Bernardo Pereira de Vasconcelos, op. cit., pp. 116-122.

138

Especialmente criticada pelo Universal foi a presidência de João José Lopes Mendes Ribeiro, em 1828 e 1829. Segundo o redator do jornal, sua "administração escandalizou a Província inteira, e cujos
Assim, embora a justificativa para tais localizações obedecessem a pretextos pragmáticos - geralmente associados à disponibilidade de "algum Edifício" prévio, "que possa aproveitar-se para o dito fim, à salubridade do Clima, barateza dos víveres para cômodo dos "Alunos", além da acessibilidade dos lugares e existência de outros estabelecimentos de ensino mais avançados, onde poderiam ser aproveitados os alunos dos estudos menores'132 - a crítica liberal não deixaria de apontar o intuito político que permeava tal perfil de atuação. Já em 1826, Bernardo Pereira de Vasconcelos, ocupando-se do assunto sobre "o lugar onde se deve estabelecer o curso juridico, e das escolas de que ele se há de compor", criticava ferrenhamente o argumento de que nas províncias "tudo é barato" - sendo antes "o avesso" - e, com ênfase ainda maior, o empenho dos Presidentes em obstarem essa "difusão de luzes"133, inversamente proporcional aos seus "mandos absolutos".

Do ponto de vista das elites mineiras que teceram uma identificação em torno do projeto liberal moderado, a crítica fundamentava-se no fato de 0 analfabetismo reinante na província converter-se em fator limitante à divulgação de suas idéias e propostas políticas, que tinham na imprensa periódica veículo privilegiado. Mediante tal realidade, a difusão dos ícones liberais em solo mineiro não poderia prescindir de práticas e formas de sociabilidade tipicamente coloniais ${ }^{134}$, como a oralidade - por meio de leituras coletivas 135 - e as concentrações para tal fim em residências particulares, indicando a própria fragilidade do controle do poder público sobre o sentido da pedagogia política cultivada nestes ambientes, uma vez que a lei determinava a inviolabilidade da casa do cidadão. ${ }^{136}$

Mas as críticas aos Presidentes da província irão se reprisar em outras falas de Bernardo Pereira137, bem como em polêmicas veiculadas pelo Universal138, principalmente após o fim da presidência de Teixeira Vasconcellos que, ocupando o cargo até 1827, dará espaço a uma "série infindável de presidentes nomeados para curtos periodos", os quais, segundo a crítica liberal, "ocupavam o posto por objetivos quase só políticos, para atender às solicitações do ministério no poder", do qual dependiam ${ }^{139}$

A nosso ver, elas esgarçam o sentido mais profundo das tensões entre as elites regionais - ansiosas por galgarem autonomia no novo arranjo político estabelecido - com uma forma de poder que lembrava os antigos Governadores de Capitania, já que também nomeada pelo Soberano, merecendo "tratamento de Excelência, e a continência militar, que competia aos antigos Capitães Generais"140.

Do ponto de vista das Câmaras municipais, as deficiências no engendramento da prosperidade material da província eram imputadas, em grande medida, à lentidão do poder regional em encaminhar as propostas por elas representadas. Mesmo entre aquelas Vilas mais próximas à Capital, eram comuns as "queixas dos Povos pela demora nas informações exigidas, e conclusão" dos negócios ${ }^{141}$, emperrando a confecção de obras públicas e o cumprimento da justiça, o que, em parte, derivava do custoso trabalho de se avaliar cada assunto, remetendo-o à instância pertinente, havendo mesmo muitas dúvidas a este respeito. ${ }^{142}$ 
fatos são patentes a todo o Brasil", havendo tantos documentos "que provam incontestavelmente as suas mentiras, e falsidades". (0 Universal, n. 564 2/3/183; idem, n. 432, pp. 2-4).

139

Francisco Iglésias, op. cit., p. 388.

140

"Lei de 20 de outubro de 1823", op. cit., Art. 21.

141

"Diários do Conselho Geral da Província de Minas Gerais, Sessão ordinária de 19 de janeiro de 1829, p. 7-8

142

Idem, Sessão ordinária de 16 de dezembro de 1830, op. cit., p. 42

143

Idem, Sessão de 26 de janeiro de 1831, op. cit., p. 144.

144

A gravidade e freqüência de tal conduta, levou o Conselho Geral a ponderar sobre a nomeação de uma Comissão especial de Posturas, conforme Sessão preparatória de 13 de dezembro de 1830. (Diários do Conselho Geral da Província de Minas Gerais, 1830, op. cit., p. 12).

145

Idem, Sessão de 26 de janeiro de 1831, op. cit., p. 144.

146

Os Diários do Conselho, bem como suas Resoluções, só se davam a conhecer depois de encerradas as sessões, segundo maneira determinada pela Lei de 20 de outubro de 1823 ("Lei de 20 de Outubro de 1823", in: Coleção das Leis do Império do Brasil de 1823, op. cit., Art. 27). Contudo, a própria agilização das impressões era uma preocupação dos Conselheiros, conforme demonstra requerimento do Sr. Assis a tal respeito. ("Diário do Conselho Geral da Província de Minas Gerais, Sessão de 9 de Dezembro de 1930, p. 19)

147

A este respeito, o Conselho atendia à requisição da Câmara de Paracatu, enviando à Assembléia Geral representação para que fossem isentos de "portes" os correios encarregados de divulgar os impressos que as Câmaras eram obrigadas a comprar. (idem rios do Conselho Geral da Província de Minas Gerais, janeiro de 1831, pp. 236-237).

148

O Universal, N. $9(05 / 08 / 1825)$ e N. 110 (29/03/1826).

149

Aqui, novamente, a legitimidade das novas instituições políticas assentava-se em práticas consagradas pelos poderes locais, cujas sessões de vereança sempre ocorreram "a portas abertas", o que foi mantido pela Lei de $1^{\circ}$. de outubro de 1828 (Coleção das Leis do Império do Brasil de 1828, Título I, Forma da Eleição, Art. 10.).

150

Expressivo deste caso, é a acusação de "cabeça de motim", dirigida pela Câmara ouropretana ao Fiscal Joaquim José Pereira, da Freguesia de Cachoeira, por ter insuflado a população local contra o poder municipal, "pelas muitas licenças que se tem tirado" obrigando os povos ainda a "tirarem novas os que as já têm", sem que tal estivesse compreendido nas Posturas. Arrogava-se, portanto, uma "autoridade que a Câmara não dá, pois é bem entendido que Fiscal não é senão acusador; e a Lei não marca atribuições de Governo", concorrendo, indiretamente, para que os organismos municipais "sejam menos prezados pelos povos esperançosos de reformas, que de uma vez os faça menor oprimido". (APM, CMOP 244, cx 4, doc 51, 14 de dezembro de 1829). A Câmara decide pela dispensa do dito Fiscal, em sessão de 8 de janeiro de 1830. (APM, CMOP 244, cx 5, doc. 3).
0 poder provincial refutava tais críticas, imputando a demora em providenciar-se acerca da "factura de Pontes e Estradas" - assunto tão premente em uma "Província central como a nossa"143 - ao "desleixo das Câmaras que se têm sucedido desde 1825", freqüentemente em falta com as remessas de suas Posturas para serem julgadas ${ }^{144}$ e com outras informações tidas por essenciais no processo de reconhecimento do espaço público a ser gerenciado. Neste contexto, tal procedimento era associado à falta de "Patriotismo" das Câmaras ${ }^{145}$, pelo não cumprimento das resoluções do Conselho, sobre as quais revelavam flagrante desconhecimento, pois, apesar de a Lei de $1^{\circ}$. de Outubro de 1828 ordenar a assinatura dos Diários do Conselho, estes só vinham a lume com grande atraso ${ }^{146}$, sendo ainda dificultosa sua vulgarização, quer pelas deficiências dos correios, quer pelas parcas finanças dos poderes locais, impedindo-lhes de arcar com tais custos ${ }^{147}$. Daí as críticas veiculadas pelo Universal, acerca das "reuniões secretíssimas" encaminhadas no Conselho Geral, desconhecendo-se os objetos de suas discussões ${ }^{148}$, ainda que a Lei de 20 de outubro de 1823 dispusesse sobre a forma destas procederem: a "portas abertas".149

As tensões que permeavam a vida política local, contudo, esgarçavam outros entraves ao bom funcionamento da coisa pública, rebatendo na própria paralisia do poder regional, em arbitrar sobre os conflitos em questão. Por um lado, as próprias Posturas Municipais, ainda quando devidamente encaminhadas e aprovadas pelo Conselho, não encontravam exata aplicação, estando suscetiveis à arbitrariedade dos individuos encarregados de observá-las, incluindo dentre estes os próprios Fiscais de obras públicas. 150

Mais gritante, ainda, era a aplicação da justiça, pois, além da grande distância que separava o Conselho de algumas localidades, havia que cumprir-se formalidades que emperravam o processo judicial, não se podendo arbitrar com desconhecimento de provas, ou sem que fossem antes ouvidos os respectivos Magistrados sobre os Requerimentos enviados ao órgão provincial151.

Além disso - e este é ponto central no tangenciamento das tensões que permearam a instalação de uma esfera pública de poder nas Minas da primeira metade dos oitocentos - a administração da Justiça era independente do Presidente e do Conselho de Província152, muito embora, "no caso em que, de continuar a servir o Magistrado, se possam seguir motins, e revoltas na Província, e se não possa esperar resolução do Imperador", ficassem autorizados a suspendê-lo, depois de ouvido.153

Este último caso, contudo, raramente se verificou. Primeiramente, porque os magistrados negavam-se a prestar depoimentos junto às autoridades provinciais e locais, quando intimados para tal, o mesmo ocorrendo quando da necessidade de cumprirem as formalidades prescritas em Lei, que implicassem qualquer atitude de subordinação a estas autoridades ${ }^{154}$. Em segundo lugar porque, mesmo quando o procedimento efetuava-se com sucesso, o afastamento do Magistrado raramente deixava de implicar seu recurso junto ao Executivo, imputando ao poder provincial a pecha de arbitrariedade. 155

Todos estes fatores, informavam a descrição do Desembargador Manuel Inácio de Melo e Souza acerca da situação da justiça em Minas, em 1827. Segundo ele, a mesma caracterizava-se pelo "deplorável estado 
Tais Requerimentos envolviam desde questões de adultério, que acabavam gerando tumultos de grandes proporções, até "ajuntamentos tumultuosos", envolvendo escravos e livres pobres e, mais freqüentemente, denúncias de abusos de jurisdição po parte das autoridades encarregadas da execução da justiça. Como exemplo destes casos, ver, respectivamente: Diário do Conselho Geral da Província, op. cit, sessão de Janeiro de 1831, pp. 133-134; 5a . sessão do ano de 1828, 5a. Sessão, pp. 28-30; Sessão de 10 de dezembro de 1830, op. cit., p. 26.

152

"Lei de 20 de outubro de 1823", in: Coleção das Leis do Império do Brasil, op. cit., ano de 1823, Art. 33.

153

Idem, Art. 34

154

0 art. 54 da Lei de $1^{\circ}$. de Outubro de 1828, reservava às Câmaras a tarefa de reconhecimento dos "titulos de todos os empregados que não tiverem superiores no lugar, a quem compete esse reconhecimento, e fazê-los registrar, tomar-Ihes juramento, e fazer publicar por editais a sua posse" ("Lei de $1^{\circ}$. De Outubro de 1828", Art. 54, in: Coleção das Leis do Império do Brasil, op. cit., ano de 1828). Em Pitangui, contudo, sucedeu-se caso expressivo do comportamento dos magistrados, quando o Juiz de Fora negou-se a prestar juramento junto à Câmara local, alegando que só o faria "quando lhe fosse ordenado por autoridade superior". (Diários do Conselho Geral da Província de Minas Gerais, op. cit., Sessão de 21 de janeiro de 1831, p. 150).

155

Esta a situação verificada em Caeté, por ocasião do afastamento do Juiz das Semarias Ordinário que, inconformado, encaminhou Requerimento à Secretaria do Estado do Negócios da Justiça, queixando-se das arbitrariedades do Conselho e pedindo interferência. (Diário do Conselho Geral da Província sessão de 19 de janeiro de 1829, pp. 7 e 8).

156

"A administração em Minas Gerais, 1827". Memória do Desembargador Manuel Ignácio de Mello e Souza, in: RAPM. Ano III, 1898, pp. 6-22.

157

Bernardo Pereira de Vasconcelos, Carta aos senhores eleitores da Província de Minas Gerais, op. cit., p.111.

158

Sobre a criação dos respectivos cargos, ver: Graça Salgado. Fiscais e Meirinhos. A administração no Brasil Colonial. Op. cit., pp. 259-262; e Lenine Nequete. 0 poder judiciário no Brasil a partir da Independência. Porto Alegre: Livraria Sulina Editora 1973.

\section{9}

Thomas Flory. El juez de paz el jurado em el Brasil imperial. Control social y estabilidad politica em el nuevo Estado. México: Fondo de Cultura. Económica, 1986, p. 81. (tradução minha).

160

Bernardo Pereira de Vasconcelos, "Carta aos senhores eleitores da Província de Minas Gerais", op. cit., p. 112.

161

Há posturas controversas entre os historiadores a respeito das reformas do judiciário, que culminaram no Código de 1832 e no Código criminal de 1830. Um breve balanço destas posições se encontra em Maria Tereza Pereira Cardoso, "Lei Branca e justiça negra; crimes de escravos na comarca do Rio das Mortes (Vila Del-Rei, 1814-1852). Campinas: Unicamp/IFCH, tese de doutoramento, capítulo 2.

162

Thomas Flory, op. cit., p. 85 da prolongada prática dos processos forenses, e a urgente necessidade de reforma", sendo os cargos da magistratura ocupados por homens "sem probidade, sem exercício do fórum, e sem as mais qualidades necessárias para tratar com o povo em negócios de tanta importância"156.

Para nossos interesses, cabe frisar que os conflitos de jurisdição nas Minas, envolvendo representantes do poder judiciário, esgarçam outros niveis do despotismo e da anarquia que aterrorizavam as elites mineiras, comprometendo o controle da autoridade provincial sobre o espaço público em construção, bem como revelando facetas importantes das tensões entre poderes locais e centralismo, justificando algumas considerações a respeito.

Primeiramente, é importante lembrar que a "entrada na modernidade política" da jovem Nação envolvia, além das reformas materiais e dos enquadramentos institucionais considerados, a necessidade de aperfeiçoamento do Judiciário.Confirmando as impressões do Desembargador supracitado, Bernardo Pereira de Vasconcelos defendia, no mesmo ano de 1827, ser esta "parte da nossa legislação a que reclama mais a atenção da Câmara dos srs. Deputados, e em que se há de fazer muita reforma".157

0 sentido desta última, registrado nos Relatórios anuais do ministro da Justiça e nos debates na Câmara dos Deputados, convergia para a defesa de uma melhor distribuição da justiça, capaz de agilizar os procedimentos processuais, o que atendia aos interesses das elites locais, propugnadoras da descentralização também na esfera do poder judiciário, cuja fonte residia no Imperador, responsável pela nomeação dos Ouvidores e Juízes de Fora. 158

Embora esta última reforma só viesse a se consumar com a elaboração do Código do Processo de 1832, foi antecedida pela criação do cargo de Juiz de Paz, pela Lei de 15 de outubro de 1827, o qual, segundo Thomas Flory, "sinalizou o começo de uma época de reforma e ascensão iminente dos liberais"159, por se tratar de um cargo eletivo para ser exercido em cada freguesia e capela filial, independente do poder centralizador e sem formação profissional especifica.

As expectativas positivas quanto à Lei seriam assim registradas por Bernardo Pereira de Vasconcelos: "Os juizes de paz, como bons pais de família, procurarão conciliar as partes que intentarem ir a juizo, e hão de obter muito mais acomodações, de que presentemente conseguem, não tendo os juizes de paz interesse nas demandas que hão de ser tratadas perante outros juizos. Os pleitos insignificantes e os delitos de pequena entidade serão julgados perante estes escolhidos do povo. Sendo um axioma incontestável que antes se previnam do que punam os delitos, é esta uma das mais belas atribuições destas novas autoridades constitucionais". 160

Entretanto, se os novos juizes converteram-se em "focos locais de apoio político liberal"161, não foram menos despreziveis os efeitos ambíguos trazidos pelo próprio intento político em dotá-los de ampla autonomia e poderes que transplantavam os de "qualquer outra instituição judicial ou de outro tipo, em sua jurisdição"162. Além disso, a ênfase no atributo da independência do cargo, em detrimento da sua eficácia, ainda que não tenha sido consensual entre os próprios liberais, implicou que, até 1832, inexistisse quaisquer codificações legais sobre suas funções. 
163

Ibidem, p. 85.

164

É este o caso mencionado numa documentação expedida pelo Juiz de Fora da Vila do Príncipe, em 18 de Agosto de 1828, onde se queixa da atuação do Ouvidor da Comarca, Francisco de Paula Monteiro de Barros, o qual, "não por más intenções suas, mas por não saber eleger um círculo de pessoas que o circundem, e ter a suficiente arte para penetrar nelas, quando falta a verdade, e quando há inveja ou paixão", acabou por abalar "a paz dos seus habitantes", desde que assumira tal jurisdição. (APM, PP 2/1- Documentação expedida/Governo Imperial, Ministérios e Assembléia Geral, cx 2, 18 de Agosto de 1828).(grifo meu).

165

Thomas Flory, op. cit., p. 106.

166

Estes últimos eleitos de forma indireta pelas Câmaras a cada três anos, para servir durante o periodo de um ano, com jurisdição sobre questões civis. (idem, p. 87).

167

"Lei de $1^{\circ}$. De Outubro de 1828", in: Coleção das Leis do Império do Brasil, op. cit., 1828, Título - Funções Municipais -, art. 24.

168

Diários do Conselho Geral da Província de Minas Gerais, op., cit, sessão de 21 de janeiro de 1831, p. 129.

169

É esta a situação registrada numa Representação enviada pela Câmara de Caeté ao Conselho Geral, na qual as criticas dirigiam-se ao então ex-Ministro do Império, José Clemente Pereira, que "a despeito das nossas Leis Constitucionais, quis ressussitar o império dos Portugueses e instituir aos Ouvidores das Câmaras a já perdida posse de expedirem Ordens aos corpos municipais, que nenhuma sujeição Ihes deve". (Diários do Conselho Geral da Província de Minas Gerais, op. cit., sessão de 07 de janeiro de 1831, pp. 62-63).
Desse modo, desde o início houve conflitos entre os juízes eleitos e os magistrados da Coroa - os juizes de fora e os ouvidores - cujo "orgulho corporativo", segundo Flory, via-se "ofendido ao ter que compartilhar uma autoridade mal definida com pessoas não profissionais eleitas pelo povo, e carentes de treinamento"163. A falta de competência, contudo, era crítica revertida pelos juízes de paz contra os próprios magistrados diretamente escolhidos pelo Imperador, representando um argumento de peso nas disputas pelo poder, já que supostamente isento de rixas pessoais e assentado num qualificativo que os diferenciava daqueles magistrados: o fato de serem conhecedores da vida local, estando supostamente aptos para interferirem em conflitos de natureza muito particular, instabilizadores da administração pública local..164

As tensões refletiram-se, ainda, no relacionamento destes representantes do judiciário com o poder provincial, pois eram freqüentes as queixas do Conselho acerca da negligência dos juizes de paz em providenciarem as informações e estatísticas solicitadas, das quais dependia um mais preciso reconhecimento do espaço público sob sua jurisdição ${ }^{165}$.

Mais gritante, porém, foram as queixas acerca dos abusos de jurisdição dos encarregados de executar a lei envolvendo, aqui, tanto os magistrados da Coroa quanto os juízes de paz e ordinários ${ }^{166}$. Na verdade, o que se observa durante todo o Primeiro Reinado - não desaparecendo nem mesmo depois da Abdicação - é uma grande confusão legal e a ausência de formulações específicas - agravada pelo desconhecimento das que existissem - para cada um destes cargos. Além disso, embora a ouvidoria e o juizado de fora tenham sido freqüentemente associados ao intuito centralizador do Executivo, remetendo ao antigo despotismo, não fugiram ao estigma mais comumente aplicado ao juizes sem preparação profissional: o desenvolvimento de laços com suas respectivas localidades, redundando em favoritismos nas disputas por eles arbitradas.

Em ambos os casos, contudo, é perceptível o agravamento dos conflitos envolvendo autoridades civis e judiciárias, após a Lei de $1^{\circ}$. de outubro de 1828, que dava nova forma às Câmaras Municipais, marcava suas atribuições e o processo para sua eleição e dos juízes de paz. Pelo Art. 24 da mesma Lei, acerca das funções municipais, as câmaras tinham suas competências limitadas, tornando-se "corporações meramente administrativas", sem poderem exercer "jurisdição alguma contenciosa"167. Mediante tais limitações de poderes, os magistrados aumentarão suas ingerências nos mais diferentes assuntos da vida local, "administrando a justiça com arbitrariedade, recebendo peitos, soltando Réu de morte e de outros crimes, sem procederem às formalidades prescritas na Lei" e perpetrando injúrias contra o Presidente da Câmara. Em casos extremos como este denunciado em Representação enviada ao Conselho pela Câmara de Pitangui, contra o Juiz de Fora local168, o Conselho, na constatação das provas, remetia a questão à Assembléia e ao Executivo, pedindo a remoção do magistrado.

Em outros, porém, os abusos partiam das próprias instâncias superiores, que transgrediam a Constituição, favorecendo magistrados de sua confiança num claro sentido centralizador ${ }^{169} .0$ Universal, expressando a tendência liberal moderada das elites mineiras, veiculará ferrenhas críticas aos abusos de jurisdição por parte destes magistrados, imputando suas ações à proteção dos "telegráficos" - expressão que aludia aos conser- 


\section{0}

Tal raciocínio é desenvolvido pelo redator do Universal, a propósito de acusações sobre a atuação despótica do Juiz de Fora de Minas Novas, Joaquim Francisco Moreira, fazendo o povo receber moed falsa da Bahia e burlando as eleições para vereadores. (O Universal, n. 355, 01/01/1830. As criticas continuam nos números seguintes, 440 e 444).

171

Sobre o atraso da instrução pública na Vila, ver: Oliveira Mello, op. cit., p. 250. Quanto às obras públicas prioritárias, apenas observamos o pleito pela abertura de uma estrada que ligasse a Comarca a Goiás.

172

APM, PP 1/52, Cx 2, doc 30

173

"Diário do Conselho Geral da Provincia de Minas Gerais", op. cit., sessão de 10 de janeiro de 1831, p. 73. Interessante notar que a associação do Ouvidor Adjuto vem desde a época do Governo Provisório. Quando da Devassa mandada instaura por José Bonifácio de Andrada e Silva, em Novembro de 1822, em várias Vilas da província, Francisco Adjuto é apontado como participando de reuniões secretas, juntamente com o ex-Governador D. Manuel de Portugal e Castro, na casa de um tal francês de nome Pachoal. Mandados trazer estes últimos para depoimento, não foram encontrados. (A Câmara Municipal e a Independência, op. cit., p. 226).

\section{4}

Indicado para o cargo pelas suas supostas qualidades de "Ministro letrado", adequado a manter o equilibrio de interesses na região, como visto anteriormente, apareceria numa Representação do Juiz Ordinário de Paracatu, Francisco Antonio de Assis, envolvido em problemas de sucessão de cargos na Vila. Segundo o representante, o Ouvidor estaria burlando o direito de "preferência do mais velho" na sucessão do cargo de Juiz Ordinário, dando preferência ao Reverendo Manoel Carneiro de Mendonça em detrimento dele, pelas relações de afinidade e intimidade, com que está ligado com o Reverendo". Especificamente, o fato de "estar casado com uma filha do atual Juiz dos Órfãos desta Vila, o Capitão João Carneiro de Mendonça, irão germano do Juiz Ordinário".( APM, PP1/30, Cx 2, doc 5, 25/fev/1826). 175

Diário do Conselho Geral da Província, op. cit., sessão de janeiro de 1831, pp. 133-134.

176

$A P M$, PP 1/52, cx 2, doc 24, 26 de fevereiro de 1831 vadores da província, que tinham no periódico 0 Telégrafo, seu principal porta-voz - supostamente interessados em manter "mandões" no poder, para garantir votos para a Câmara dos Deputados. 170

É justamente a partir de conflitos desta natureza que a Comarca de Paracatu ganha relevo nos Diários do Conselho Geral da Província. Apartada, em grande medida, das conquistas materiais que favoreceram setores das elites do centro-sul mineiro171, as Representações dirigidas pela Câmara paracatuense ao órgão provincial relatavam diversos problemas envolvendo, desde o tabelionato de alguns Distritos - que infrigiam a Constituição, movidos, muito provavelmente, por perseguições de cunho pessoal ${ }^{172}$ - até, e principalmente, a magistratura, em particular o quarto Ouvidor da Comarca, Francisco Garcia Ajuto, tido por Bernardo Pereira de Vasconcelos como "um dos magistrados mais arbitrários da Província"173, cuja atuação patrocinou a arbitrariedade de alguns Juizes Ordinários dos Julgados setentrionais do Desemboque, Araxá e São Romão.

$\mathrm{Na}$ tentativa de pinçar os aspectos tangiveis das rivalidades entre estas autoridades, os poderes civis locais e o governo provincial, ficam patentes duas tendências que, a nosso ver, singularizam os conflitos políticos na região. Por um lado, o fato já mencionado de que as disputas aí aparecem, quase sempre, esgrimidas no plano das relações de parentesco, o que não deixava de envolver nem mesmo as autoridades mais supostamente ilesas, como era o caso do antigo Ouvidor Antonio Limbo de Abreu. ${ }^{174}$

Tal natureza dos conflitos limitava sobremaneira as possibilidades de avaliação e arbitramento do Conselho, o que era por este reconhecido como "difícil em tais lugares e circunstâncias"175. Por outro lado, principalmente a partir da Lei de $1^{\circ}$. de outubro de 1828 , observa-se uma verdadeira tendência centrifuga em alguns Julgados setentrionais, instigada pelo judiciário, tanto em relação ao poder civil municipal - negando-se a prestar-lhe submissão, no que a lei determinava, e declarando completa autonomia -, quanto em relação à própria província mineira, conformando um bloco regional alternativo.

Expressivo do primeiro movimento, fora o Ofício do Juiz Ordinário do Desemboque, Antonio Joaquim de Castro, remetido ao Conselho pelo então presidente da Câmara de Paracatu, Francisco Antonio de Assis, em 26 de fevereiro de 1831. Neste, declarava "ser aquele Julgado independente daquela Câmara", recusando "prestar-Ihe obediência, por estar este negócio afecto ao Poder Executivo, e à Assembléia Geral"176, o que o presidente da Câmara refutava, argumentando que se "fora lícito desobedecer as Autoridades legitimamente constituidas com o pretexto de haver representado aos superiores destas, também poderão eles com seus cúmplices erigir seus Julgados em Cabeças de Comarcas e até em Capitais de Províncias. Mas, "a isso não se arojam, porque as Autoridades contra quem seria um tal atentado, são revestidas de jurisdição necessária e suficiente, não só para o desempenho de seus deveres, mas tb para coibirem as agressões que fazer-Ihes se ouse; pelo contrário, na Lei de 10. de Outubro de 1828 encontra-se esta notável Lacuna". 177

Mais grave, porém, era o conteúdo da Representação enviada pelo Juiz de Paz Suplente do Julgado de São Romão ao Conselho, na qual relatava o episódio em que o "Ouvidor Geral e Corregedor da Comarca 
Diários do Conselho Gerald a Província de Minas Gerais, op. cit., sessão de 11 de Dezembro de 1830 pp. 63-64. Apesar da gravidade do caso, assombrando pelos atos "irregulares e arbitrados" descritos, a Comissão de Representações fica impossibilitada de arbitrar sobre os mesmos, pela destituição de provas.

179

Tanto o termo do Araxá, como do Desemboque fizeram parte da província de Goiás até 4 de abril de 1816, quando um Alvará incorporou-o à Comarca de Paracatu. Mesmo assim, esta incorporação só teve efeitos em matérias civis, de maneira que os Registros dos Julgados continuaram sendo guarnecidos por Tropas de Goiás. (Raimundo José da Cunha Matos (org.), Corografia Histórica da Província de Minas Gerais (1837). Belo Horizonte: Imprensa Oficial, 1979, vol. 2, p. 182).

180

A idéia de incorporação de parte do noroeste mineiro a um bloco alternativo com as províncias setentrionais teria longo fôlego, seduzindo inclusive membros da elite política nordestina. Assim, já em 1830 era encaminhado à Câmara dos Deputados um projeto do deputado pernambucano Luis

Cavalcanti para a criação de uma "Província do São Francisco", que não chegou a entrar em discussão. A proposta retornaria em 1850 - agora sob defesa da bancada bahiana, com apoio da pernambucana e piauiense, sob a forma de outro projeto, que não passou da segunda discussão - e, novamente, em 1873, com projeto que incorporava parte dos territórios mineiro, bahiano e pernambucano, perdurando as discussões até 1874 , sem que o projeto vingasse. Segundo Mata-Machado, a esta época, uma das principais oposições dos deputados liberais mineiros à desanexação de parte do território residia no fato de ai terem importante eleitorado. (Bernardo Mata-Machado, op. cit., pp. 101-113)

181

Diários do Conselho Geral da Província de Minas Gerais, op. cit., sessão de 29 de janeiro de 1831, p. 192

182

Idem, sessão de 26 de janeiro de 1831, p. 147

183

Idem, sessão de 03 de janeiro de 1829. 0 problema da circulação de cobre falso proveniente da Bahia era especialmente grave nas regiões limítrofes de

S. Romão e Minas Novas, implicando, dentre outras conseqüências, a carestia dos víveres.

184

Idem, sessão de 14 de março de 1829.

185

Idem, sessão de 06 de março de 1829. de Paracatu, entrando (...) com o Juiz Ordinário e o de Órfãos, com o Fiel do Registro do Rio das Velhas da parte da Província de Goiás, seis soldados da mesma província, e muitos outros, proclamara que esse território não pertence ao Termo da Vila de Paracatu, nem à Província de Minas Gerais, e declarando ter ali vindo para castigar os funcionários públicos nomeados pela Câmara de Paracatu, atacou com ameaças e palavras descompostas ao Fiscal Dezidério Mendes dos Santos, prendeu sem culpa formada e conservou em prisão por dez dias ao Procurador Simão Ferreira de Figueiredo, e mandou prender ao Porteiro pelo fato de publicar Editais da Câmara de Paracatu".178

A nosso ver, esgarçando uma contigüidade geográfica, histórica, econômica e mesmo antropológica179, entre as elites do noroeste mineiro e as do Vale do São Francisco, passando pelo Alto Sertão Bahiano, a idéia do desmembramento acima referida parece extremamente fecunda na perquirição das diversidades que, remetidas a processos de ocupação específicos em seu embasamento material, bem como na sua cronologia, desvendam, em cada parte da província, vínculos regionais também distintos, com forte poder de interferência na constituição de sentimentos de diferenciação identitária e de interesses que, se não se opunham direta e principalmente ao poder central instalado no Rio de Janeiro, tensionaram fortemente as relações de poder nas esferas locais e em nivel regional, instabilizando o processo de consolidação do Estado e da Nação brasileiros. ${ }^{180}$

Incumbido de arbitrar sobre tão diversificados assuntos e conflitos, que permearam o processo de construção de um espaço público de poder na província mineira e adensaram-se neste curto período de 1828 a 1831, o Conselho de Governo examinava as Representações e Posturas encaminhadas pelas Câmaras, insistindo no princípio de "aprovar quanto Ihe não for diametralmente oposto aos princípios constitucionais, ou ofensivo dos interesses municipais".181

Neste sentido, se por um lado desaprovava despesas consideradas supérfluas, como a pretendida pela Câmara de Campanha com um retrato de D. Pedro - merecendo a reprovação do Conselho sob o argumento de que "Patriotismo é seguir a lei" por ele feita182 -, por outro, incorporava demandas e sugestões consideradas prementes, como a que, seguindo exemplo do Juíz de Paz de São Romão, autorizava que o cobre falso provindo da Bahia, apesar da Resolução de 27 de Novembro de 1827 determinando sua retirada de circulação, continuasse sendo utilizado enquanto não se obtivesse resolução superior, evitando que houvesse paralização nas transações correntes. ${ }^{183}$

Simultaneamente, recomendava às Câmaras que tratassem de fazer os respectivos juizes de paz eleitos observarem o Regimento de 15 de outubro de 1827, a fim de manterem-se limitados às suas competências ${ }^{184}$, procurando não só "evitar as rixas", mas "quanto Ihes for possível, manter a harmonia entre os habitantes de seus Distritos, a fim de prevenir quaisquer desordens prejudiciais e muitas vezes promotoras de graves conseqüências". 185

Por fim, cabe ainda mencionar o que se converteu no procedimento 
186

APM, PP 2/1, Cx 2- Doc 8- 59 escritos, com vários encaminhamentos de pedidos de arraiais e julgados pedindo elevação a vilas, mudança de comarca, etc...

187

Relatório do presidente Marechal José Manoel de Almeida, ano de 1830, op. cit., p. 103. Segundo Relatório do ano seguinte, existiam perto de 400 Juizes de Paz na Província, como resultado destes desmembramento administrativo (Relatório do Presidente Manoel Ignácio de Mello e Souza, ano de 1831, op. cit., p. 111).

188

Diários do Conselho Gerald a Província de Minas Gerais, op. cit., sessão de 12 de fevereiro de 1831 p. 204

189

Haberbas insiste nesta idéia, ainda que a esfera pública, segundo ele, continuasse sendo um princípio organizacional do ordenamento político da sociedade.(Jürgen Habermas. Mudança estrutural da esfera pública. Trad. Flavio R. Kothe, Rio de Janeiro: Tempo Brasileiro, 1984,. p. 17) mais freqüente do governo provincial, mediante os diversos problemas relatados: o desmebramento administrativo da província. Assim, atendendo à solicitação de diferentes Termos ${ }^{186}$, representava, segundo Relatório do Presidente de Província do ano de 1830, a necessidade de criação de "mais trinta, na proporção de 10 mil a 14 mil almas para os distritos mais populosos, e de 6 mil a 10 mil para os menos povoados". Também representava a "precisão de Julgados em alguns lugares e de quarenta freguesias além de 97 existentes na proporção de 4 mil para 6 mil almas", esperando, com tais providências, cessarem "as diferenças sobre limites, e os conflitos de jurisdição"187. Seguindo esta lógica, na mesma sessão em que o Conselho debatia o referido Ofício do Juiz Ordinário do Desemboque, informando desligamento da Câmara paracatuense, encaminhava-se proposta para a criação das seguintes Vilas naquela Comarca: a de São Romão, compreendendo em seu Termo o Julgado de mesmo nome, e a Vila de São Domingos do Araxá, incorporando os Julgado do Desemboque e Araxá. ${ }^{188}$

Em outros termos, acreditamos ser correto compreender este processo incipiente de formação de uma esfera pública de poder nas Minas de inícios do XIX, como indicando um movimento simultâneo, ainda que não linear e tampouco desprovido de tensões e conflitos, de ampliação histórica da esfera pública, com esvaziamento de suas funções ${ }^{189}$. Tal movimento teria implicações decisivas nas articulações entre o centro imperial e a periferia mineira, nos arranjos políticos acalentados por seus diferentes setores, que dariam o tom das alternâncias de sentidos e recriação das continuidades, sob as quais deve ser pensado este processo de transformação de comunidades em Nação. Tal análise, contudo, fica ao encargo de reflexões posteriores. 